\title{
MYSTERIUM SEPTIFORMIS ECCLESIAE
}

\author{
In septem ecclesiis [...] \\ intelligitur una Ecclesia catholica \\ propter septiformem Spiritum gratiae \\ Cezary z Arles (VI s.)
}

Artykuł ten jest skróconą wersją kilku rozdziałów mej nie publikowanej jeszcze pracy o ikonografii Salwatora, o roli Apokalipsy w Kościele wczesnochrześcijańskim i o pierwotnym programie dekoracji mozaikowej bazyliki Salwatora na Lateranie, zwanej dziś popularnie San Giovanni in Laterano.

Zwyczaj wiązania kościołów i ołtarzy po siedem i podporządkowywanie ich często ósmemu, hierarchicznie wyżej postawionemu, oraz pochodzenie tego zwyczaju uszły dotychczas uwagi historyków, tak Kościoła, jak i sakralnych zespołów architektonicznych. Tym tłumaczyć należy niewielką ilość przykładów, jakimi dysponuje badacz poruszający ten temat i opisujący zjawisko tak niegdyś ważne w życiu Kościoła pierwszego i drugiego tysiąclecia. Spodziewać się wolno, iż wraz ze zwróceniem na nie uwagi, ilość przykładów znacznie wzrośnie.

Grupowanie po siedem kościołów, kaplic, ołtarzy, kandelabrów ma swoje źródło w Apokalipsie św. Jana i w jej egzegezie. Począwszy od wieku III Apokalipsa wywierała wpływ głęboki. i trwały na życie Kościoła, na jego organizację terytorialną, na liturgię i sztukę sakralną. Na szczególną uwagę zasługuje obecność w nim siódemki, liczby najczęściej się pojawiającej w wizjach apokaliptycznych ${ }^{1}$. Odegrała ona wielką rolę w czasach organizowania się Kościoła w imperium rzymskim, a jej wpływ wyśledzić można jeszcze w wieku XX.

\footnotetext{
* W przypisach i tekście artykułu zastosowano następujące skróty:

BJ - Biblioteka Jagiellońska w Krakowie

CSEL - Corpus scriptorum ecclesiasticorum Latinorum

DACL - Dictionnaire d'archéologie chrétienne et de liturgie

$\mathrm{MPH}$ - Monumenta Poloniae historica

PL - Patrologia Latina
}

${ }^{1}$ Zob. Apokalipsa 1 - 5, 8, 12, 17, 21 (7 kościołów azjatyckich, 7 kandelabrów, 7 gwiazd, 7 aniołów, 7 lamp, księga siedmiokroć zapieczętowana, baranek o 7 rogach i 7 oczach, 7 aniołów z 7 trąbami, smok o 7 głowach z 7 diademami, 7 aniołów niosących 7 czasz, 7 pagórków, 7 królów itd.). 
Starożytny kult siódemki w krajach wschodnich, znany także ze Starego Testamentu, zaadoptowali egzegeci Apokalipsy, obdarzając tę liczbę (jak również dwie liczby na nią się składające: 3 i 4) ważnymi symbolizmami, co zapewniło jej wielowiekową egzystencję. Najstarszy zachowany komentarz: Scholia in Apocalypsin beati Joannis, napisany przed rokiem 304 przez Wiktorinusa, biskupa Poetavio (Ptuj), pozwala zrozumieć powstanie pewnych zwyczajów liturgicznych, systemu siódemkowego organizacji Kościoła oraz programów ikonograficznych dekoracji najświętszych miejsc świątyń chrześcijańskich.

Według Wiktorinusa, zespół siedmiu kościołów, do których pisał listy św. Jan (Efez, Smyrna, Pergamon, Tiatira, Sardes, Filadelfia i Laodycea), to symbol Kościoła powszechnego, czyli katolickiego, oświeconego siedmioma Duchami, czyli Duchem siedmiokształtnym. Ów „typ siedmiu kościołów” był, jak twierdzi Wiktorinus, rozpowszechniony „w całym świecie”2. Mogłoby to znaczyć, że już w III wieku wiązano ideowo siedem sanktuariów.

W IV wieku o symbolizmie apokaliptycznej siódemki pisali: św. Ambroży (Mediolan), św. Hieronim (Betlejem), Ticonius (północna Afryka). W VI wieku Cezary z Arles w swej Expositio in Apocalypsin b. Joannis wyjaśniał jej znaczenie podobnie jak Wiktorinus w wieku III: „Tak w Azji jak i w całym świecie przez siedem kościołów rozumie się Kościól powszechny i także łaska Ducha św. jest siedmiokształtna" (PL 35 kol. 2418). Późniejsi teologowie (wieków VIII i IX), jak Autpertus, Beda, Alkuin, Beatus, Strabon, Berengaudus znali również wagę symbolizmu apokaliptycznej siódemki. Widzieli w niej liczbę doskonałą, zawierającą ideę jedności i uniwersalności Kościoła napełnionego łaską siedmiu darów Ducha św. ${ }^{3}$ Jeszcze w XII wieku Anzelm z Laôn powtarzał, iż siódemka oznacza cały Kościól, oświecony siedmiokształtnym Duchem i że w siedmiu lampach (Ap 4,5) widzieć należy dary Ducha św. ${ }^{4}$ Przeanalizować więc należy wpływ Apokalipsy i jej egzegezy na różne dziedziny życia Kościoła począwszy od epoki Pokoju (Małego i Wielkiego), epoki jego swobodnego na ogół kształtowania się i organizowania.

$2,[\ldots]$ in toto orbe septennatim ecclesias omnes septem esse nominatas [...] in his ergo septem ecclesiis, unius Ecclesiae catholicae fideles sunt [...] quia Spiritus sanctus septiformis virtutis datus est in potestate ejus a Patre”. Wiktorinus pisał też, że ów „typ siedmiu kościołów” przestrzegany był i stosowany już przez św. Pawła, który pisał do siedmiu gmin, inne zaś listy skierował do poszczególnych osób (CSEL 49 s. 26 - 29; PL 5 kol. 320). Komentarz Wiktorinusa przyjąl niemal bez zmian św. Hieronim (oba komentarze wydał razem J. Hausleiter: CSEL 49 s. 12-61). Interesującą wzmiankę przytacza Peregryn z Bordeaux w r. 333. Zapisał on, że w Jerozolimie, na Sionie, obok pałacu Dawida stało niegdyś siedem synagog, z których przetrwała tylko jedna (PL 8 kol. 791).

${ }^{3}$ PL 96 kol. 694, Pl 17 kol. 843 - 1055, PL 100 kol. 1086 - 1102, PL 117 kol. 937 - 1220.

${ }^{4}$ Anselmus Laoniensis, Glossa ordinaria, [w:] PL 114 kol. 711 - 714. Tę Glossę przypisywano Walafridowi Strabonowi. 


\section{Organizacja siódemkowa Kościoła}

W połowie III w. biskup Rzymu Fabian utworzył w wiecznym mieście siedem regionów kościelnych ${ }^{5}$. Późniejsi egzegeci wiązali ten akt z Apokalipsą. Berengaudus przypomniał w swym komentarzu, że święte miasto Jerozalem Niebiańska podzielona była na „septem partes” (PL 17 kol. 845). W tym samym zapewne czasie ustanowiono siedem regionów podmiejskich, a w dwóch z nich wzniósł kościoły Konstantym Wielki ${ }^{6}$. Najstarszym natomiast zespołem siedmiu kościołów, potwierdzonym w źródłach, jest wielka rzymska fundacja Konstantyna. W Liber pontyficalis wymieniono pierwszego chrześcijańskiego cesarza jako donatora bazyliki biskupiej na Lateranie oraz z nią związanych i jej podporządkowanych sanktuariów: baptysterium lateraneńskiego oraz usytuowanych wokół Rzymu sześciu bazylik (św. Piotra, św. Pawła, śś. Piotra i Marcelina, św. Krzyża, św. Wawrzyńca i św. Agnieszki) ${ }^{7}$. Razem miały one tworzyć, zgodnie z egzegezą Apokalipsy, obraz jedności i powszechności Kościoła (rys. 13). Z czasem usunięto z tego zespołu baptysterium, traktując je łącznie z bazyliką Salwatora na Lateranie oraz wyeliminowano dwie bazyliki: św. Agnieszki i śś. Piotra i Marcelina, wprowadzając na ich miejsce dwie inne: św. Marii Większej (Sta Maria Maggiore) i św. Sebastiana. Owe siedem kościołów zwie się do dziś i wyróżnia jako „le sette chiese di Roma”, a ich związek z Apokalipsą potwierdzają źródła jeszcze z XVI wieku (il. 2) ${ }^{8}$.

Gdy w Rzymie wznoszono nowe kościoły, grupowano je po siedem, podporządkowując ósmemu, którym była jedna z pozostałych czterech bazylik patriarchalnych wiecznego miasta: Sta Maria Maggiore, S. Pietro, S. Paolo, S. Lorenzo; ich ilość, ich wezwania i powiązania z tymi bazylikami, są nam znane z dwunastowiecznego przekazu Jana Diakona, historyka Lateranu, opierającego się w swych relacjach na starszych źródłach i opracowaniach. Zgodnie z jego szczegółowym przekazem były to następujące „siódemki”, a raczej siedem kościołów rzymskich plus jeden:

"Cardinales Sanctae Mariae majoris ii sunt: Sanctorum Apostolorum, Sancti Cyriaci in Thermas, Sancti Eusebii, Sanctae Pudenzianae, Sancti Vitalis, Sanctorum Marcellini et Petri, Sancti Clementis.

Cardinales Sancti Petri sunt ii: Sanctae Mariae Transtiberim, Sancti Chrysogoni, Sanctae Caeciliae, Sanctae Anastasiae, Sancti Laurentii in Damaso, Sancti Marci, Sanctorum Martini et Silvestri.

${ }^{5}$ Ch. Piet ri, Roma christiana, Romae 1976, s. 135, 148, 650.

${ }^{6}$ Według Liber pontificalis (ed. T. Mo m m s e n, 7. 1 s. 81) Konstantym Wielki ufundował kościoły w Ostii oraz , in civitate Albanense”, a więc w dwóch z siedmiu regionów podmiejskich Rzymu, wymienionych w Vita s. Stephani w VIII wieku (DACL 8 s. 1585) i w XII wieku przez Jana Diakona (PL 194 kol. 1550).

${ }^{7}$ Liber pontificalis, ed. D u ch es ne, t. 1, Paris 1886, s. 173 - 175, 177-183, 187 (Silvester).

${ }^{8}$ Zob. teksty u dołu ryciny z r. 1575 w albumie Maria Cantario (BJ Oddział Zbiorów Graficznych, 9040, ryc. 149). Dziękuję Panu Kustoszowi Piotrowi Hordyńskiemu za zwrócenie mi uwagi na tę rycinę. 


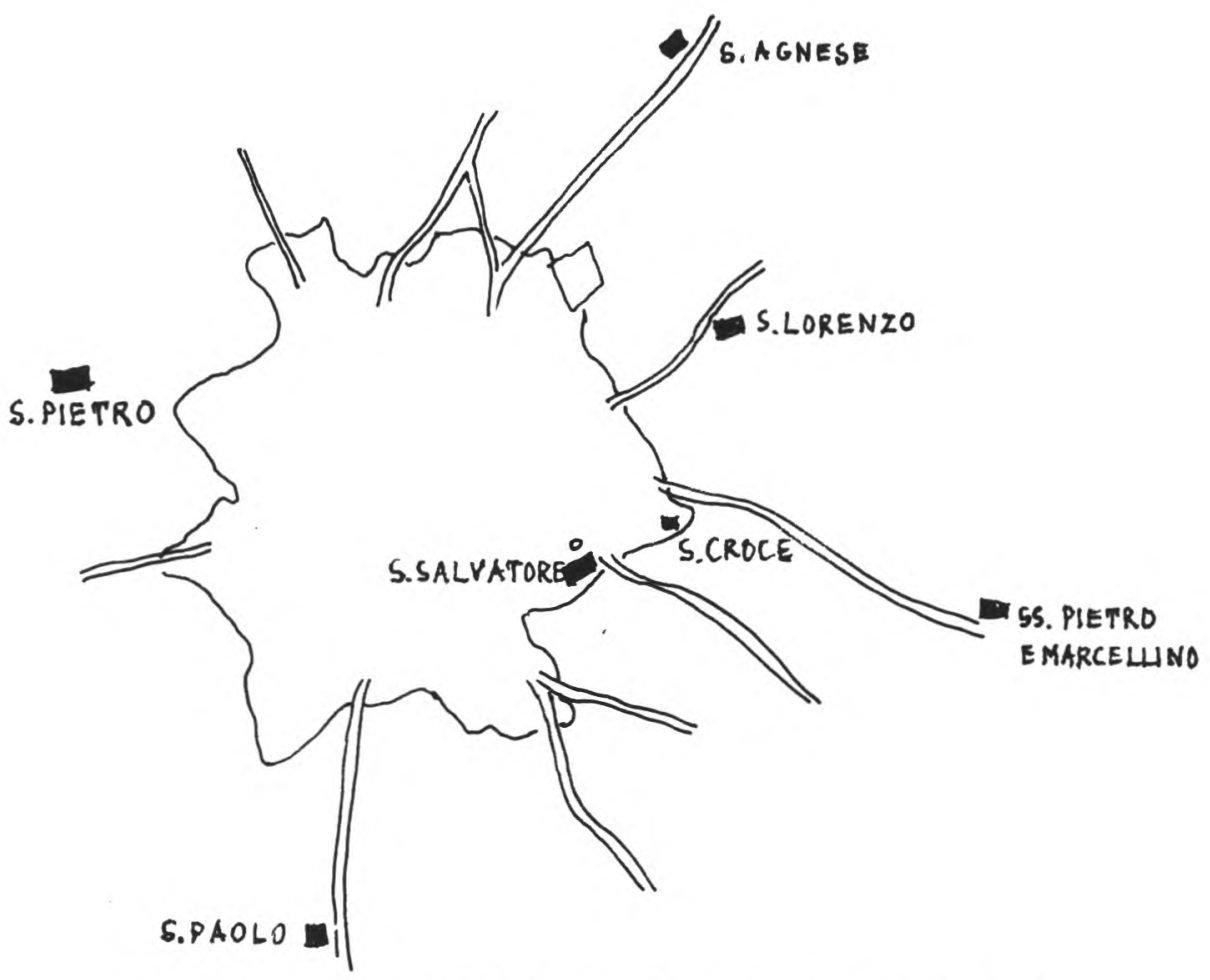

Rys. 13. Rzym. Siedem sanktuariów (plus katedra) ufundowanych przez Konstantyna Wielkiego.

Cardinales Sancti Pauli sunt ii: Sanctae Sabinae, Sanctae Priscae, Sanctae Balbinae, Sanctorum Nerei et Achillei, Sancti Sixti, Sancti Marcelli, Sanctae Susannae.

Cardinales Sancti Laurentii sunt ii: Sancta Prasseda, Sancti Petri ad Vincolo, Sancti Laurentii in Lucina, Sanctae Crucis in Jerusalemme, Sancti Stephani in Coelio monte, Sanctorum Johannis et Pauli, Sanctorum Quattuor Coronatum" (PL 194 kol. 1558).

Jan Diakon wymienił w swym zestawie tylko kościoły wczesnochrześcijańskie, co świadczyć może o ich „siódemkowym” powiązaniu już w tej epoce (V - VIw.).

Slady siódemkowego „systemu” organizacji terytorialnej Kościoła odnajdujemy nie tylko w Rzymie. Wydaje się, że Konstantyn Wielki wprowadził go również do Konstantynopola. Jego zachowanie się w czasie akcji włączania nowych terenów do starożytnego Byzancjon celem wzniesienia miasta, które miało nosić jego imię (i nosiło je ponad 1200 lat), wydało się już dziwne historykowi Filostorgiuszowi. Zapisał on, iż cesarz Konstantyn kroczył pieszo (!), 
trzymając w ręce lancę i odmierzając nią nowe ziemie dla swego miasta. Gdy członkowie towarzyszącej mu świty usiłowali go powstrzymać przed przyłączaniem tak wielkich obszarów, cesarz odpowiedział zagadkowo, iż nie może się zatrzymać dopóki nie uczyni tego ten, który kroczy przed nim ${ }^{9}$. Czy na tę akcję Konstantyna oddziałał tekst z rozdziału 21,15 Apokalipsy? Napisano tam, iż jeden z siedmiu aniołów mierzył święte miasto, Jerozolimę niebiańską, złotą trzciną. Konstantyn, jak anioł Apokalipsy, odmierzal (złotą zapewne) trzcinąlancą tereny pod siedem „,apokaliptycznych” regionów podmiejskich. W siódmym, zwanym Hebdomon wzniósł kościół św. Janowi Ewangeliście, niekwestionowanemu wówczas autorowi Księgi Objawienia ${ }^{10}$. Dziś, z siedmiu znane są jedynie nazwy czterech regionów, a ich imiona wywodzą się od cyfr: Deuteron od 2, Triton od 3, Hexakiomion od 6 i Hebdomon od 7. Jest możliwe, że również miasto Konstantynopol było podzielone na siedem regionów kościelnych, gdyż o jednym z nich wiadomo, iż za czasów Konstantyna nosił nazwę jednego z siedmiu kościołów, do których pisał listy św. Jan. Było to Filadelfion ${ }^{11}$.

Ślady istnienia siódemkowego systemu podziału terytorialnego odnajdujemy także w północnej Afryce. W oparciu o wykopaliska archeologiczne stwierdzono, iż wczesnochrześcijańska Kartagina podzielona była na siedem regionów, z których każdy posiadał kościół i baptysterium ${ }^{12}$.

W następnych wiekach pierwszego tysiąclecia odnajdujemy ów system w różnych regionach świata chrześcijańskiego. Począwszy od w. V znane są
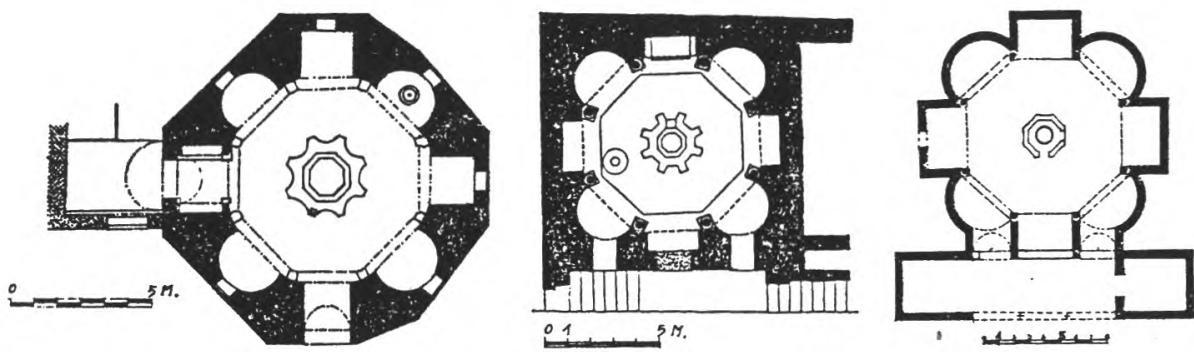

Rys. 14. Baptysteria w Albendze, Fréjus i Nowarze (wg Verzonego)

${ }^{9}$ Ex ecclesiasticis historiis Philostorgii, [w:] PL 65 kol. 87, 417.

10 Gdy Teodozjusz Wielki budowal kościół w Hebdomon św. Janowi Chrzcicielowi, głowe tego świętego zdeponowano w pobliskim kościele św. Jana Ewangelisty (Patria Constantinopoleos, $\S 145$; C. Mango, The Art of the Byzantine Empire 312-1453, Toronto-Buffalo-London 1986.

${ }^{11}$ P. Sh e ra rd, Constantinople. Iconography of a Sacred City, London 1965, s. 8. Filostorgiusz przekazał, że pierwszego dnia uroczystej konsekracji miasta Konstantynopola (11 V 330) uroczysta procesja prowadzona przez kapłanów chrześcijańskich skierowała się w stronę regionu miejskiego, zwanego Filadelfion.

${ }_{12}$ K. D u n b a bin, The mosaics of Roman North Africa, „Bulletin Monumental” 137:1979 s. $1018,1078$. 
sanktuaria centralne, głównie baptysteria, wyposażone w siedem apsyd (ósma to wejście do wnętrza), które zawierały zapewne siedem „symbolicznych” ołtarzy (Mediolan, Albenga, Frejus, Nowara, Nevers, Lomelle, Würzburg, Deutz, Settino Vittone).

W Italii siedem kaplic w Mediolanie zapewne jeszcze przed VII wiekiem otaczało katedrę (rys. 15) ${ }^{13}$. Przy kościele św. Stefana w Bolonii przetrwał do dziś zespół siedmiu sanktuariów zwanych w VIII i IX wieku „Nową” lub „Świętą Jerozolimą" i noszących wezwania siedmiu rzymskich kościołów (rys. 16) ${ }^{14}$.

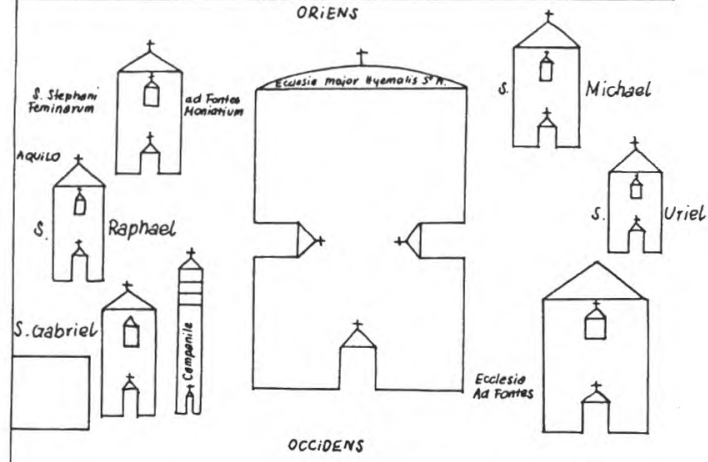

Rys. 15. Mediolan. Katedra i jej siedem sanktuariów (wg Giuliniego)

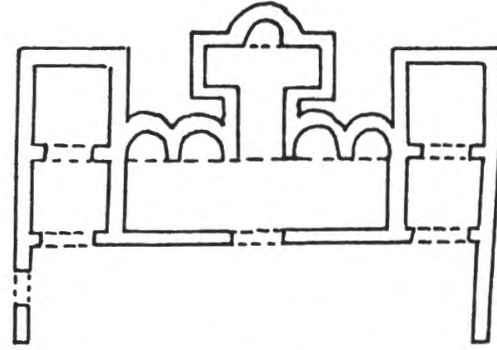

Rys. 16. Bolonia. Plan siedmiu sanktuariów w kościele św. Stefana

W Galii, na jednej z wysp Lerins, wzniesiono siedem kaplic w pobliżu kościoła, który pierwotnie był zapewne poświęcony Salwatorowi ${ }^{15}$. Krypta kościoła św. Medarda z IX wieku w Soissons (rys. 17) zawiera także siedem sanktuariów. W Centuli Angilbert opat benedyktyńskiej wspólnoty ufundowal, wraz z Karolem Wielkim, siedem „kościołów” i siedem okolicznych sanktuariów związał administracyjnie i liturgicznie z głównym kościołem klasztornym, noszącym wezwanie Salwatora. Do wnętrza tej świątyni wprowadził siedem oltarzy stacyjnych (rys. 18) ${ }^{16}$.

W Andenne nad Mozą św. Bega ufundowała w VII wieku siedem kościołów. Według legendy, miejsce dla ich wzniesienia wskazała kura i jej siedem kurcząt ${ }^{17}$. Nasuwa się pytanie, czy słynna srebrna kura i siedem kurcząt (sym-

${ }^{13}$ Rekonstrukcja Giuliniego u C. He it z a: Recherches sur les rapports entre architecture et liturgie à l'époque carolingienne, Paris 1963, s. 225.

${ }_{14}$ G. A p r a to, Bologna. Complesso di S. Stefano, Bologna 1966, s. 281-284.

15 DACL 8 s. 2623.

${ }^{16}$ F. L ot, Hariulf. Chronique de l'Abbaye de Saint-Riquier (Ve siècle-1104), Paris 1894, s. 67. Sam Angilbert, fundator opactwa, nazwał „kościołami” wszystkie siedem sanktuariów, choć trzy $\mathrm{z}$ nich były skromnymi oltarzami, umieszczonymi w trzech bramach prowadzących do atrium (,paradisus").

${ }^{17}$ L. Ré a u, Iconographie de l'art chrétien, t. 3 cz. 1, Paris 1958, s. 191. 


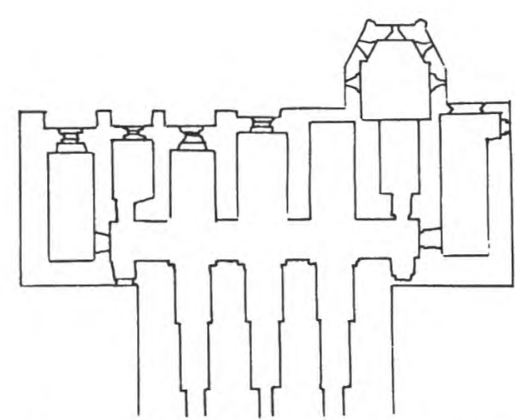

Rys. 17. Soissons. Siedem kaplic w krypcie kościoła św. Medarda

Rys. 18. Centula. Plan opactwa św,. Rychariusza i jego siedmiu „kościołów” (wg Heitza): 1. Św. Salvatora, 2. Św. Piotra i Rychariusza, 3. Matki Bożej i śś. Apostołów, 4. Sw. Benedykta, 5. Archaniola Michała, 6. Archanioła Gabriela, 7. Archanioła Rafała. Zob. także il. 4

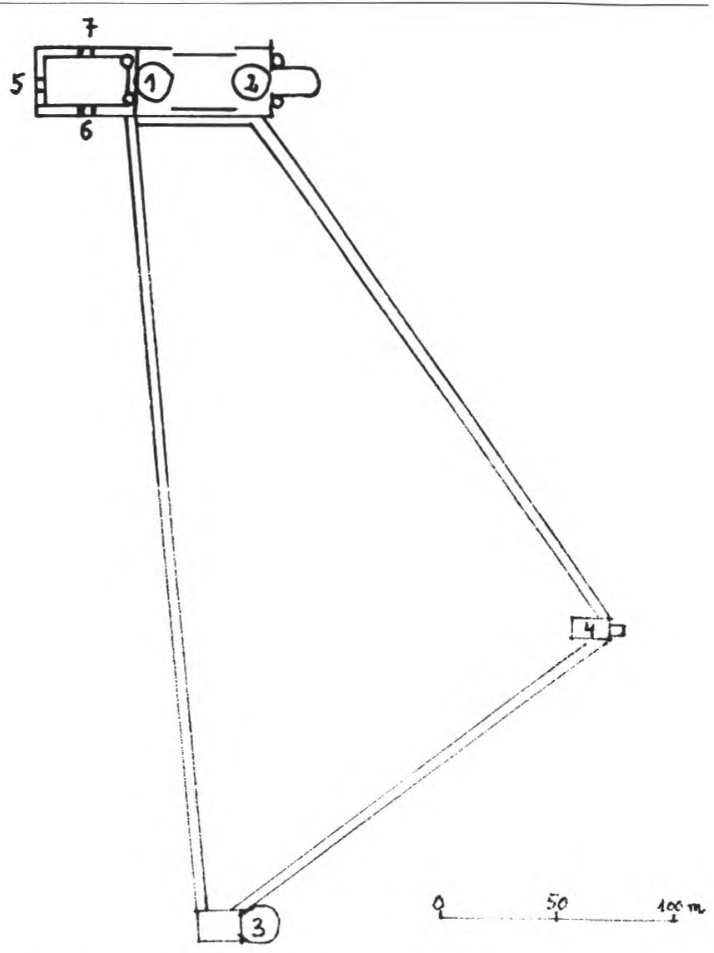

bol siedmiorakiego Kościoła) ze skarbca katedralnego w Monzy (VII w.) związana jest z tą, czy też z inną podobną fundacją (il. 11).

W Irlandii, w Inishmore, na wyspie Aran przetrwały ruiny kościołów, zwane „Seven Churches” (il. 12). Znanych jest również siedem sanktuariów z Glendalough (?). Być może tak liczne niewielkie kaplice, rozsiane na terenie Irlandii, są pozostałością symbolicznych siódemek.

W drugim tysiącleciu trwa nadal zwyczaj wiązania siedmiu sanktuariów z kościołem wyższej hierarchii (z katedrą lub kościołem opackim, noszącymi, podobnie jak w pierwszym tysiącleciu, wezwanie Salwatora), z triadą rodziny katedralnej lub opackiej. Liczba sanktuariów w tym symbolicznym zespole sakralnych budowli zwiększa się więc z siedmiu lub ośmiu do dziesięciu, a więc do liczby zawierającej również znaczenie symboliczne, w której trójka, symbol św. Trójcy, „ukoronuje” siódemkę.

$\mathrm{Na}$ jedenastowiecznej miniaturze w Bibliotece Watykańskiej widnieje siedem kościołów $(3+4)$ przy Monte Cassino. Powyżej tego przedstawienia ukazano opata Dezyderiusza stojącego z księgą w ręce przed św. Benedyktem, a siedem innych ksiąg leży u stóp opata (il. 5). Poza nimi widoczne są dwie wielkie bazyliki i wieża między nimi (Biblioteka Watykańska Lat. 1202). Do tej samej tradycji należy kształtowanie chórów romańskich i gotyckich z siedmioma kaplicami promienistymi. 
W dwunastowiecznej Polsce Piotr Włast (Włost) ufundował siedem kościołów, zgodnie z przekazem Kroniki wielkopolskiej ${ }^{18}$. W zwiefalteńskiej Kronice Ortlieba przypisuje mu się wzniesienie aż siedemdziesięciu kościołów ${ }^{19}$. Gdy Litwa, ostatni kraj pogański w Europie, przyjęła w r. 1387 chrzest pod patronatem Kościoła polskiego, król Władysław Jagiełło wzniósł katedrę w Wilnie i siedem kościołów na prowincji ${ }^{20}$. Żywa więc była jeszcze tradycja systemu siódemkowego, choć nie wiemy, czy nadal wiązano go z Apokalipsą ${ }^{21}$.

W Etiopii, w Lalibeli, około r. 1200 wykuto w skałach dwa wielkie kościoły, poświęcając je Salwatorowi i Matce Bożej (rolę baptysterium pełni po dziś dzień płynąca obok rzeka, zwana Jordanem) oraz siedem mniejszych sanktuariów ${ }^{22}$. Zespół siedmiu kaplic, siedmiu rzeźbionych figur męskich z krzyżem i zwojem w rękach w jednym z siedmiu kościołów (zwanym kościołem Golgoty), przykład unikatowy w sztuce Etiopii, a także odczytywanie z głównego filaru stojącego w kościele Matki Bożej idei jedności Kościoła, dają świadectwo wpływu symbolizmów apokaliptycznych na formację tej „Nowej Jerozolimy”.

Na chrześcijańskim Wschodzie ów siódemkowy system organizacji Kościoła daje się również wyśledzić w drugim tysiącleciu. Jest on uchwytny w Grecji na górze Atos, w Meteorze, w Mistrze. Wiele przykładów dostarcza nam Ruś, gdzie stosuje się go jeszcze w wieku XVIII. Na ogół siedem kościołów wiąże się tam z soborem pod wezwaniem Spasa, czyli Przemienionego Salwatora. W większych miastach Rusi (lecz także na wsiach), jak w Kijowie, Moskwie, Pskowie, Włodzimierzu, Nowogrodzie, podporządkowano siedem cerkwi soborowi, a z kolei siedem soborów - soborowi metropolitalnemu ${ }^{23}$. Stosowano więc na Rusi taki sam system jak we wczesnochrześcijańskim Rzymie. Zanim zgrupowano nową „siódemkę” kościołów, upływało niekiedy kilka wieków.

${ }_{18} \mathrm{MPH}$ (seria 2) 8 roz. 32.

${ }_{19}$ MPH 2 s. 3. Jan Długosz i Benedykt z Poznania zredukowali ich liczbę do 43, Łuszczkiewicz — do 50, Sobieszczański — do 59, T. H. Orłowski — do 20. Jeśli uznamy Kronikę Ortlieba za źródło w jakimś stopniu wiarogodne, to może Piotr Włast wzniósł siedem wielkich kościołów oraz wokól nich po siedem mniejszych sanktuariów, a więc razem 56 budowli sakralnych (nie 70). Przykładem takiej jego działalności mógłby być klasztor św. Wincentego na Ołbinie we Wrocławiu, gdzie główny kościół otaczają mniejsze sanktuaria, a jedno z tych siedmiu (?), kaplicę św. Michała, darował opactwu biskup wrocławski Robert w r. 1139 (zob. T. H. O rł ow s k i, Czy Piotr Wtast zbudowat 70 kościołów?, [w:] Mecenas, kolekcjoner, odbiorca, Warszawa 1984, s. 50, il. 6 na s. 51).

20 J. D t u go s z, Annales seu Cronicae incliti Regni Poloniae, liber X, Varsoviae 1985.

21 Odkrywane na Wawelu resztki malych sanktuariów preromańskich, rozmieszczone wokól katedry, są zapewne pozostałością siedmiu kaplic. Ten sam siódemkowy system zastosowano zapewne w Mikulčicach na Morawach.

22 Opis tego zespołu sanktuariów zob.: H. Helfritz, Äthiopien. Kunst im Verborgenen, Köln 1974, s. 199-230. Nieco późniejszy jest tam kościół św. Jerzego, usytuowany w pewnej odległości od „symbolicznego" zestawu kościołów i kaplic.

${ }^{23} \mathrm{~A}$."G r a b a r, Cathédrales multiples et groupement d'Églises en Russie [w:] L'Art de la fin de l'antiquité et du Moyen-Age, t. 2, Paris 1968, s. 921, 922 n. 
Siódemkowe wyposażenie wnętrz budowli sakralnych

Symboliczną siódemkę wprowadzono również do wnętrz kościołów, przede wszystkim biskupich i opackich. Już Konstantyn Wielki darował bazylice Salwatora na Lateranie siedem ołtarzy, siedem kandelabrów, siedem lamp i po siedem naczyń liturgicznych (do odprawiania ofiary przy siedmiu ołtarzach „apokaliptycznych") ${ }^{24}$. Następne tego rodzaju fundacje znane są dopiero z wieku VIII i IX. W r. 772 Karol Wielki obdarował kościół Salwatora w opactwie benedyktyńskim w Aniane siedmioma ołtarzami, siedmioma kandelabrami i siedmioma lampami (naśladownictwo donacji Konstantyna Wielkiego?). Ufundował również siedem kandelabrów dla kościoła opactwa św. Dionizego pod Paryżem. W wieku XII opat Sugeriusz zastąpił je, już zniszczone, siedmioma nowymi ${ }^{25}$. Tuż przed rokiem 799 ustawił Angilbert „in vestibulo” kościoła Salwatora w benedyktyńskim opactwie św. Rychariusza w Centuli siedem ołtarzy stacyjnych ${ }^{26}$. W roku 878 papież Jan VIII konsekrował uroczyście siedem ołtarzy w kościele Salwatora w opactwie benedyktyńskim śś. Piotra i Pawła we Flavigny ${ }^{27}$. Tak na Lateranie, jak i w Aniane, w Centuli i we Flavigny, oprócz siedmiu ołtarzy symbolicznych stał ołtarz główny, poświęcony Salwatorowi. Natomiast w biskupim oratorium Salwatora w Germiny-des-Près (ok. 806 r.) było nie siedem plus jeden, lecz tylko siedem ołtarzy (sześć stanęło na sześciu apsydach, siódmym był ołtarz główny, usytuowany pierwotnie zapewne pod kopułą wieży).

Jeszcze w XVIII wieku wprowadzano do kościołów wyższej hierarchii siedem uprzywilejowanych ołtarzy, opatrując je często napisami: „Altare unum ex septem privillegiatum” lub „Altare unum ex septem”. Nawiązaniem do tej tradycji w XX wieku była budowa kościoła klasztoru benedyktyńskiego w Brugge, nazwanego „Zevenkerken” czyli „Siedem Kościołów”. Ustawiono tam siedem ołtarzy (w sześciu kaplicach i w prezbiterium), poświęcając je świętym tytularnym siedmiu kościołów rzymskich, na wzór, jak stwierdził mnich tego opactwa, kościoła św. Stefana w Bolonii, gdzie „siedem ołtarzy nosi wezwania siedmiu bazylik Rzymu"28.

${ }^{24}$ Liber pontificalis, ed. T. Momm sen, t. 1 p. 52; DACL 8 kol. 1547.

${ }^{25} \mathrm{P}$. B 1 o ch, Siebenarmige Leuchter in Christlichen Kirchen, „, Wallraf-Richartz-Jahrbuch” 23 : 1961 s. 89; Vita Benedicti Anianensis, [w:] PL 103 kol. 857; Sergii abbatis Liber de rebus in administratione sua gestis, I, $34 \mathrm{~A}$.

26 W głównym kościele opactwa pod wezwaniem Salwatora stało, jak pisał fundator Angilbert, 11 ołtarzy (F. L o t, jw., s. 67), z tych siedem było stacyjnych (tamże, s. 59-60, 305).

27 V. C. He it z, Architecture et liturgie processionnelle à l'époque préromane, „Revue de l'Art" 1974 s. 38.

${ }^{28}$ Składam podziękowanie Ojcu M. Coune'owi, opatowi Zevenkerken, za przesłanie mi danych o opactwie. 


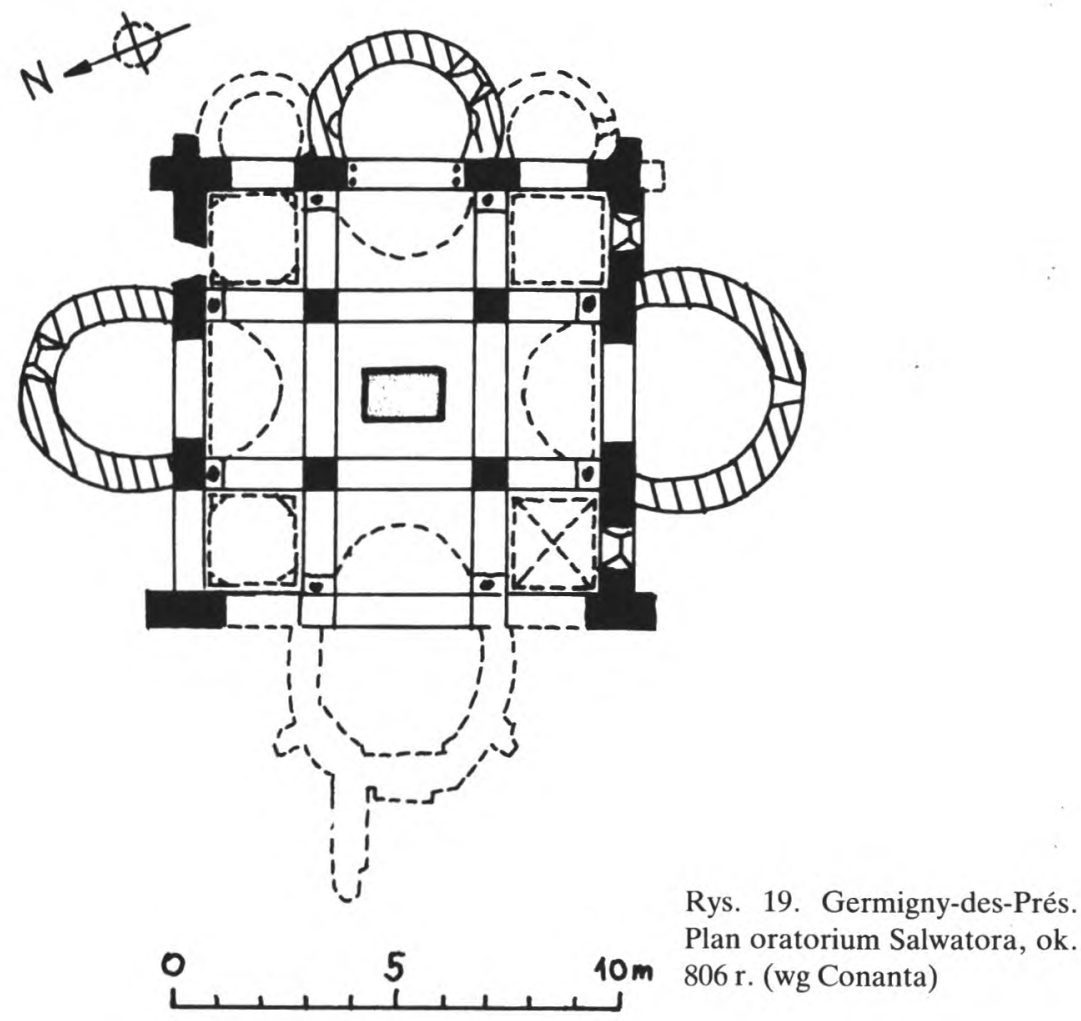

\section{Liturgia}

Lektury apokaliptyczne stanowiły i stanowią do dziś ważny element łacińskiej liturgii paschalnej. Do wieku VII czytano zapewne cały tekst Apokalipsy, po czym dokonano wyboru tekstów. Najstarsze ich zestawy przetrwały w Liber comicus (VII w.) dla liturgii mozarabskiej i w lekcjonarzu z Luxeuil (VII w.) dla liturgii gallikańskiej29. Zgodnie z Liber comicus, w najważniejsze dni świąt Zmartwychwstania czytano $\mathrm{z}$ rozdziału 1. Apokalipsy opis ekstatycznej wizji św. Jana na wyspie Patmos: w Wielką Sobotę — polecenie napisania listów do siedmiu gmin azjatyckich, wizję Syna Człowieczego wśród siedmiu kandelabrów (Ap. 1,9-18), i ponownie w Wielką Niedzielę teksty zawierające wyjaśnienie znaczenia siedmiu kandelabrów i siedmiu gwiazd (Ap. 1, 1-18): gwiazdy to aniołowie siedmiu kościołów, a siedem kandelabrów to siedem kościołów. W inne wyznaczone dni okresu paschalnego przekazywano wiernym treść listów. Według lekcjonarza z Luxeuil, w poniedziałek i wtorek oktawy

${ }^{29}$ Zob. C. Heitz, Recherches sur les rapports..., s. 129 n. 
paschalnej obowiązywała lektura wizji siedmiu kandelabrów oraz listów do Efezu, Smyrny i Pergamonu (Ap. 1, 14, 2, 7, 2, 8-17).

Apokaliptyczna siódemka wpłynęła również na siódemkowy układ procesyjny. Z pierwszego tysiąclecia znane są dwa jego szczególowe opisy, oba $\mathrm{z}$ epoki karolińskiej: Institutio Sancti Anghilberti abbatis de diversitate officiorum, zredagowane przez opata Centuli około roku $800^{30}$, oraz Primus ordo Romanus z opisem starych rzymskich zwyczajów z około połowy IX w. ${ }^{31}$

W wielkich procesjach w Centuli brały udział także delegacje siedmiu sanktuariów regionalnych, związanych z opactwem, każda z krzyżem ze swego kościoła. Na czele procesji szli ministranci niosący wodę święconą i kadzielnice, a za nimi postępowali „septem et septem”: siedmiu mnichów z relikwiarzami, siedmiu z krzyżami z kościoła opackiego, siedmiu diakonów, siedmiu subdiakonów, siedmiu egzorcystów, siedmiu lektorów, siedmiu ostiariuszy. Następnie, respektując nadal układ siódemkowy, szli: schola cantorum ze swymi sztandarami, mnisi z opactwa, „szlachetni” panowie i panie. Za nimi postępowali niosący siedem krzyży z siedmiu kościołów regionalnych, młodzi chłopcy i dziewczęta, mieszkańcy zamku Centula i na końcu lud („mixtus populus”) oraz chorzy i starcy. Angilbert wyjaśniał, iż owym układem siódemkowym czci się Kościół, napełniony siedmioraką łaską Ducha św. ${ }^{32}$

Dla tej „,choreografii” procesyjnej wzorem stały się zapewne zwyczaje rzymskie, jak wolno sądzić z opisu w Primus ordo Romanus. „In processione Apostolici ad stationem et in ingressu sacrari" brali udział: siedmiu prezbitrów z miasta i z suburbiów (7 i 4 razy po 7?), siedmiu akolitów, siedmiu diakonów, siedmiu subdiakonów, siedmiu notariuszów, mnisi, schola cantorum, lud wszyscy „per ordines”, a więc niewątpliwie w porządku „septem et septem”, zgodnie z już ustalonym zwyczajem, stosowanym jeszcze w XII i XIV wieku w Essen ${ }^{33}$.

Wewnątrz świątyń zmieniał się porządek procesji. Siódemki dzielono na 3 i 4, tak jak to uwiecznił dziewięciowieczny artysta na plakietkach sakramentarza Drogona (il. 3). Ów podział miał również ustalone, a znane nam z egzegezy Apokalipsy, znaczenia ideowe ${ }^{34}$. $\mathrm{Z}$ obu stron głównego ołtarza bazyliki Salwatora na Lateranie ustawiało się (z jednej strony trzech, $\mathrm{z}$ drugiej czte-

${ }^{30}$ Teksty Angilberta i Kronikę opactwa w Centuli opublikował F. Lot (jw.).

${ }^{31}$ PL 78 kol. $937 \mathrm{n}$.

${ }^{32}$ F. Lot, jw., s. $299-30$.

${ }^{33} \mathrm{~F}$. A r e n s, Der Liber ordinarius des Essener Stiftskirche und seine Bedeutung für die Liturgie. Geschichte und Topographie des ehemaligen Stiftes Essen, Essen 1901, s. 40.

34 Już św. Cyprian (III w.) widział w trójce symbolizm trynitarny, a w czwórce - cztery żywioly. Primasius (VI w.) wyjaśniał obie liczby w duchu neoplatońskim: ,ad animam tres pertinent, ad corpus quattuor" (PL 68 kol. 797). Według Alkuina doskonała liczba siedem dzieli się na 3 i 4 symbolizując: 3 - św. Trójcę i trzy cnoty; 4 - oznacza cztery Ewangelie i cztery cnoty główne. „Słuszne więc", pisał Alkuin, ,że liczba siedem to Kościół powszechny” (PL 101 kol. 1216, 1089, 1092). 
rech) siedmiu akolitów z kandelabrami w rękach, siedmiu notariuszy i siedmiu subdiakonów ${ }^{35}$.

Apokaliptyczną wizję siedmiu kandelabrów wprowadzono również do liturgii mszy, a najstarszym znanym źródłem jest Expositio brevis liturgiae Gallicanae, przypisywane biskupowi Paryża Germanusowi (VI w.). Kapłanowi wchodzącemu z księgą Ewangelii do sanktuarium dla odprawienia ofiary towarzyszyli niosący siedem kandelabrów z płonącymi świecami. Autor tego tekstu wyjaśnił, iż światło tych świec symbolizuje siedem darów Ducha św. lub światło Prawa ${ }^{36}$. Według Primus ordo Romanus, gdy kończyła się procesja i biskup Rzymu Apostolicus wchodził do bazyliki Lateraneńskiej, poprzedzało go siedmiu akolitów niosących siedem kandelabrów z zapalonymi świecami ${ }^{37}$. Panvinio, szesnastowieczny historyk Lateranu, potwierdził istnienie tego liturgicznego zwyczaju, dodając, iż przed głównym ołatrzem zapalano również siedem lamp $\mathrm{p}^{38}$.

Kościół długo pielęgnował tę wczesnochrześcijańską tradycję, wprowadzoną już za czasów papieża Sylwestra I i cesarza Konstantyna Wielkiego do bazyliki Salwatora na Lateranie. Przypomnieć tu trzeba, iż zawierały one ważne dla całego Kościoła idee: kandelabry - siedem kościołów azjatyckich, obraz jedności i uniwersalności Kościoła, a lampy — siedem Duchów Bożych i ich siedem darów (zgodnie z Ap. 1,20 i 4,5). Jan Diakon wspomniał, że w bazylice Salwatora na Lateranie przechowywano siedem kandelabrów, „quae fuerunt in priori tabernaculo", a więc wierzono, iż były darem Konstantyna ${ }^{39}$. Dziś stawia się na ołtarz tylko sześć kandelabrów, zacierając ich piękny, tradycyjny symbolizm i jego związek z Apokalipsą, natomiast w starych kościołach pozostawiono niekiedy siedem lamp wiszących przed ołtarzem ${ }^{40}$.

W średniowieczu (Braunschweig) i jeszcze w wieku XVII (Poitiers) obchodzono święto „siedmiu kandelabrów”41. W wieku XVI, dzięki św. Filipowi z Neri odnowiono w Rzymie kult siedmiu kościołów, wprowadzając od roku 1550 zwyczaj pielgrzymowania do nich ${ }^{42}$. Liczne procesje krążyły pomiędzy „le sette chiese di Roma”, a stary symbolizm tej siódemki upowszechniały na-

35 PL 78 kol. 940.

${ }^{36}$ PL 72 kol. 89; P. Bloch, jw., s. 56.

${ }^{37}$ PL 78 kol. 940.

38 Zob. rękopisy: Archiwum Lateraneńskie A. 68; Biblioteka Watykańska lat. 61110, 6781; Ph. La u e r, Palais du Latran, Roma 1911, s. 410 n. Siedem lamp przed ołtarzem głównym zapalano w dniu święta Salwatora i miały się one tam palić cały rok (tamże, s. 442).

39 PL 194 kol. 1548.

${ }^{40}$ W tekście hebrajskim Księgi Izajasza werset 11, 2 zawiera tylko sześć darów Ducha św., lecz szósty posiada w hebrajskim dwa znaczenia: pobożność i bojaźń Bożą. Rozróżniano je w II w. przed Ch. w Septuagincie, w tłumaczeniu greckim, a także w Wulgacie św. Hieronima. Egzegeza czasów nowożytnych (od XVIII w.?) pozostawiła, wbrew wielowiekowej tradycji, jedynie dar bojaźni Bożej, zacierając stary symbolizm siódemki. Wyrażam wdzięczność o. J. Paściakowi OP, który mi wyjaśnił to zjawisko.

${ }^{41}$ Ch. Roh ault de Fle ury, La messe, t. 6, Paris 1888, s. 35; P. Bloch, jw., s. 56.

42 A. Her z, Cardinal Cesare Baronio's Restoration of SS. Nereo ed Achilleo and S. Cesareo d'Appia, „The Art Bulletin” 4:1988 s. 593. 


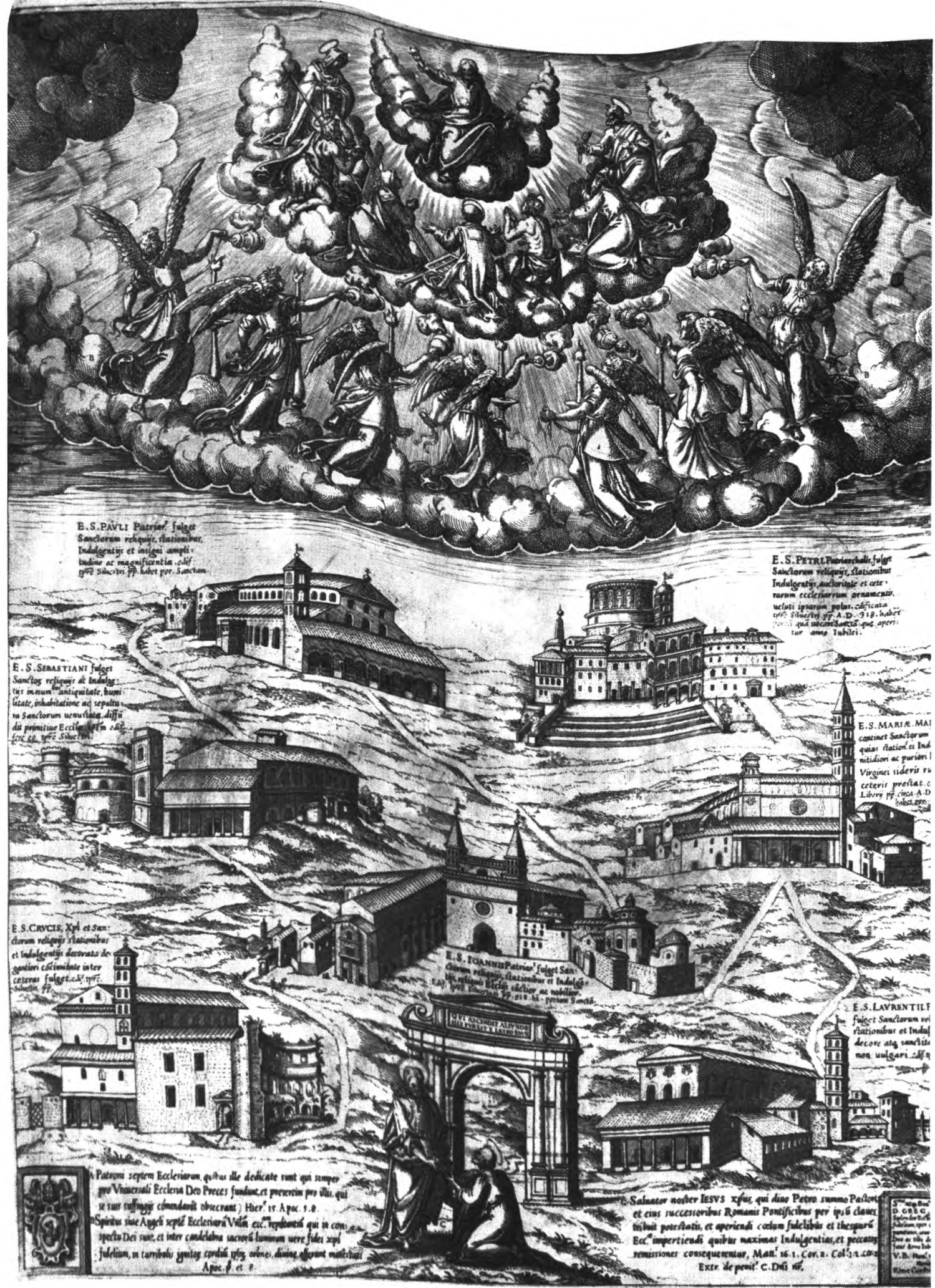

1. Le sette chiese di Roma, rycina z r. 1575, Biblioteka Jagiellońska w Krakowie, sygn. 9040 ryc. 149 (fot. A. Rzepecki). 


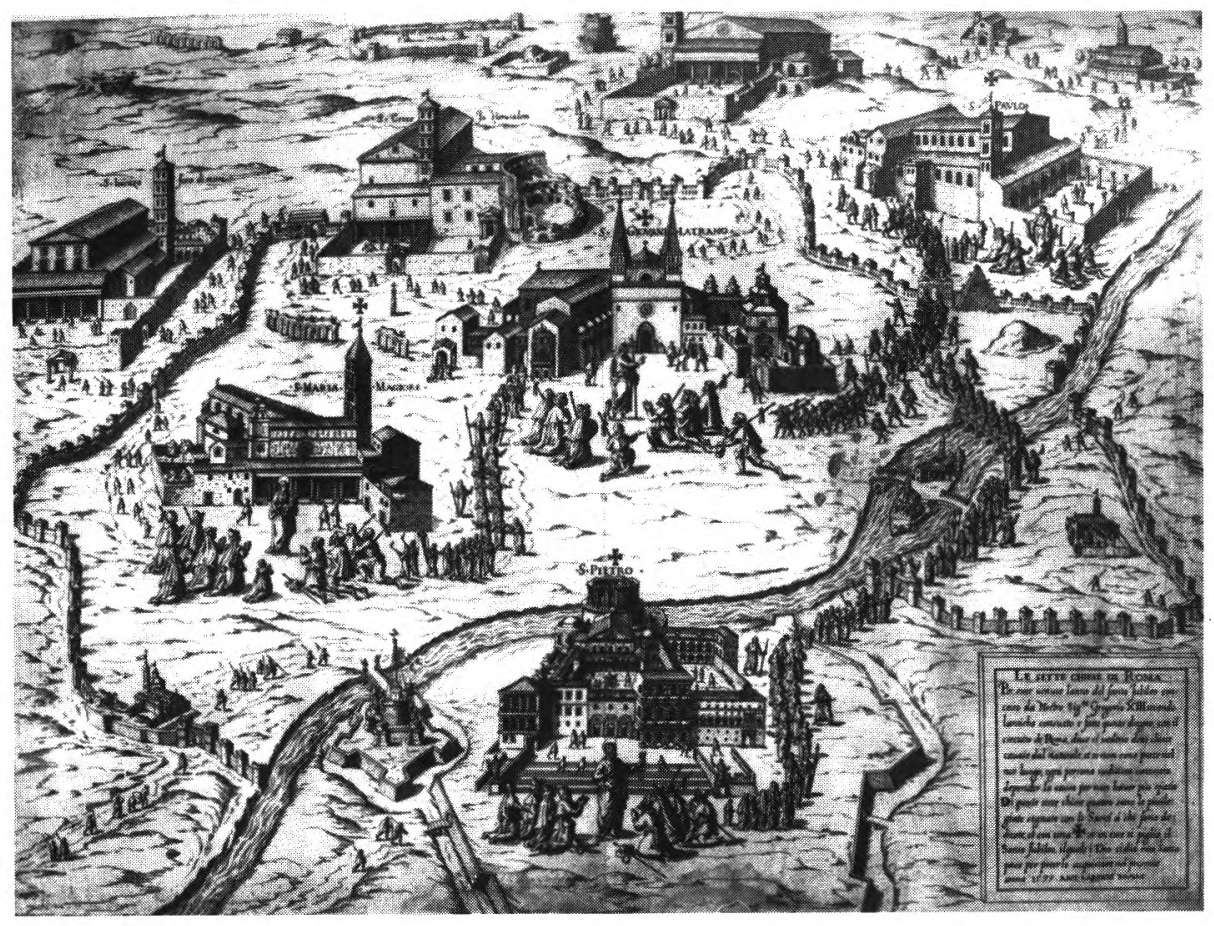

2. Le sette chiese di Roma, rycina A. Lafrery'ego z 1575 r

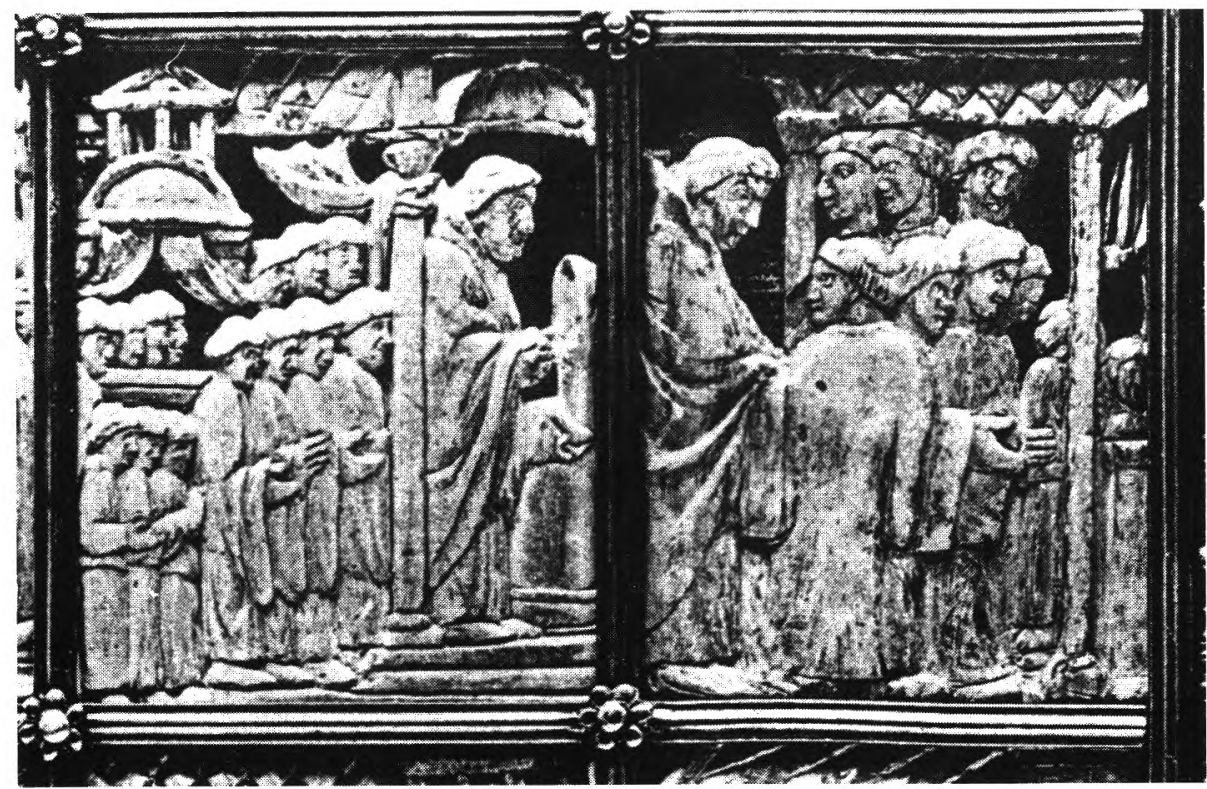

3. Sakramentarz Dragona, IX w., wg Goldschmida (fot. A. Rzepecki). 


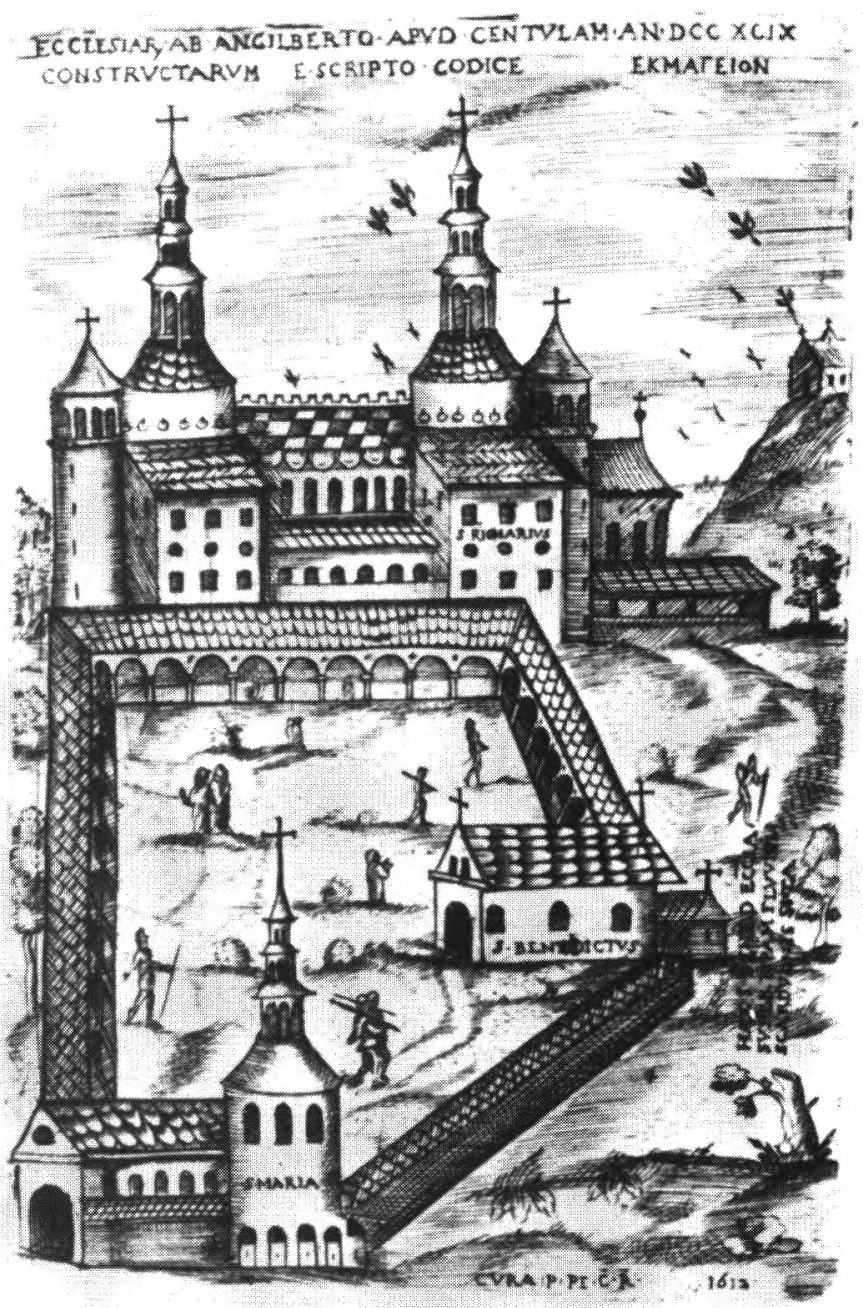

4. Opactwo św. Rychariusza w Centuli, XI w., wg Heitza (fot. A. Rzepecki).

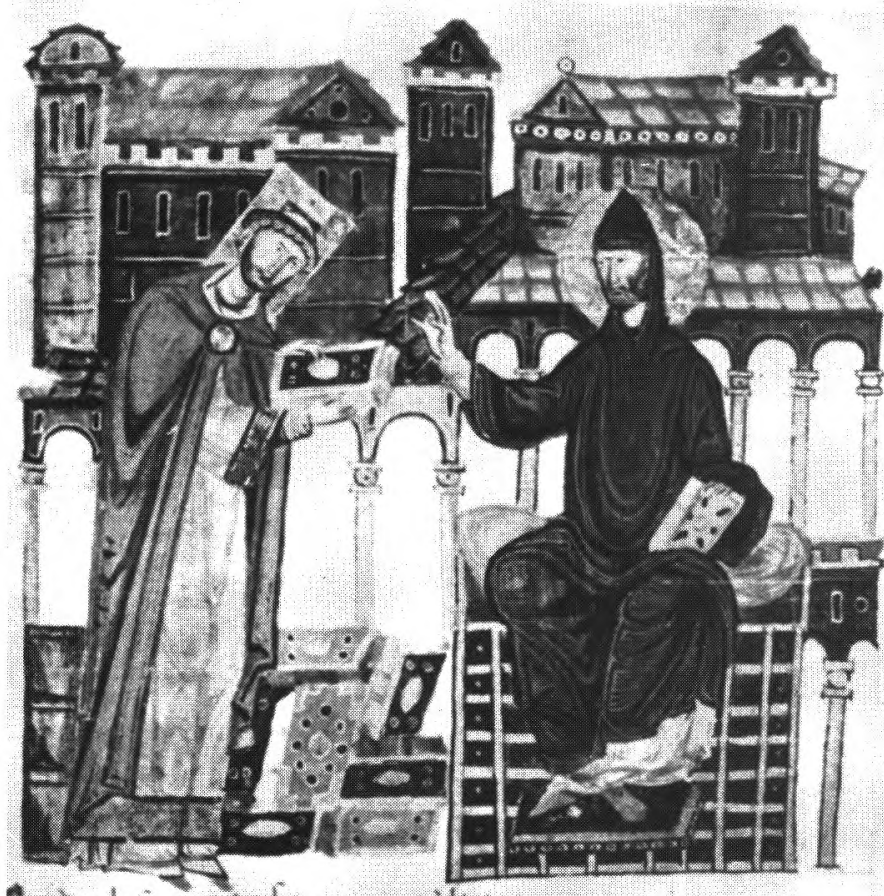

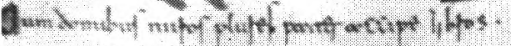

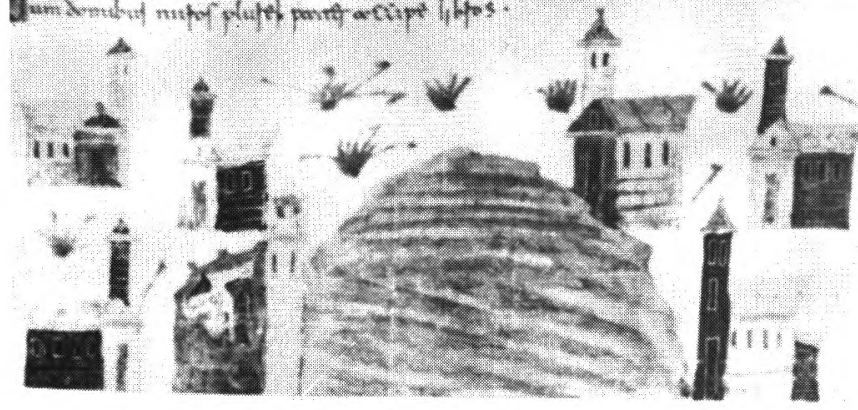

5. Rękopis (z Monte Cassino) Vat. Lat. 1202 f. 2r, XI w., wg Dodwella (fot. A. Rzepecki). 


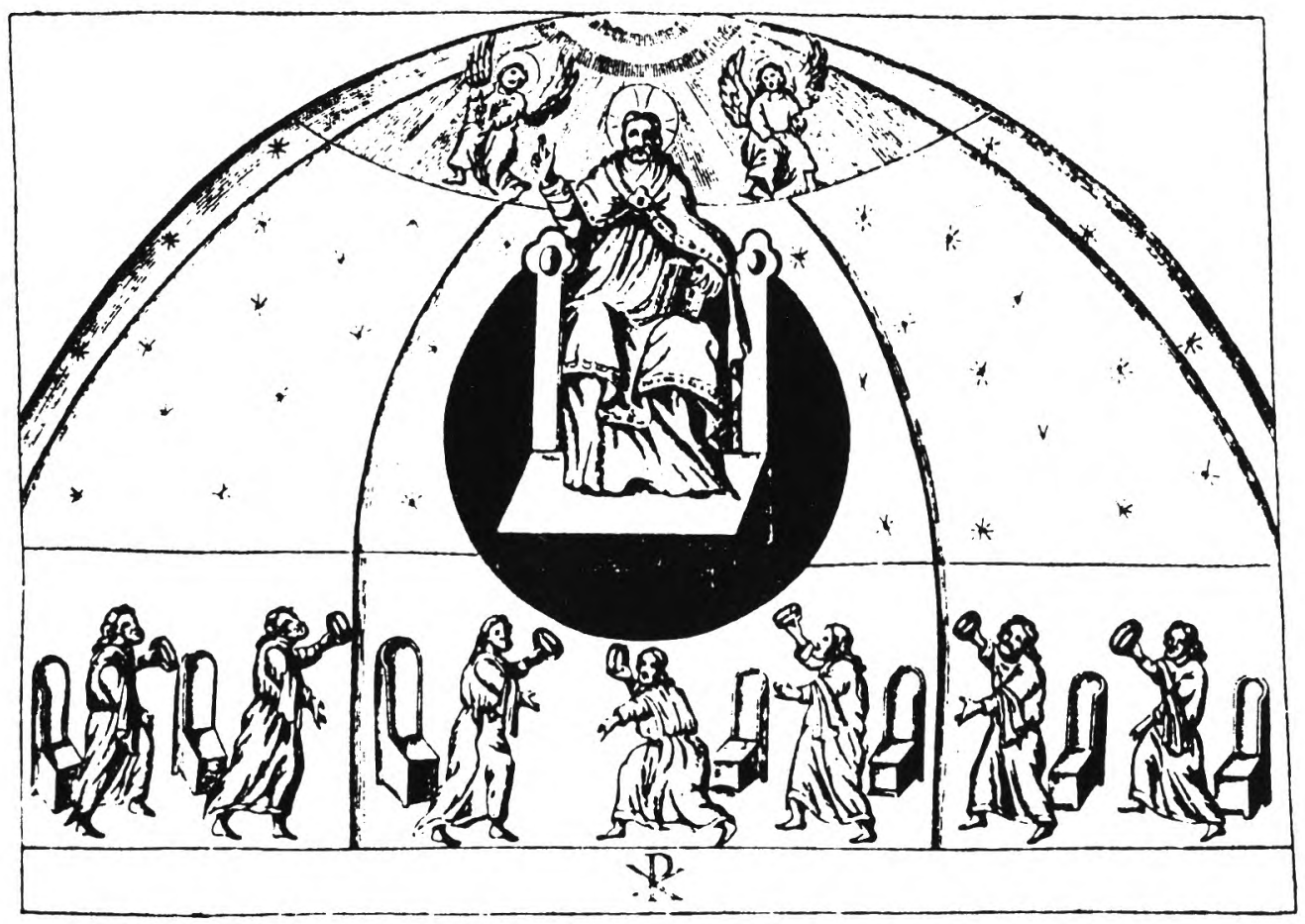

6. Akwizgran. Kaplica pałacowa Karola Wielkiego p.w. Salwatora. Mozaiki trzech przęseł kopuły, wg Ciampiniego.

7. Tamże. Rekonstrukcja mozaiki na kopule (J. Kalinowska).

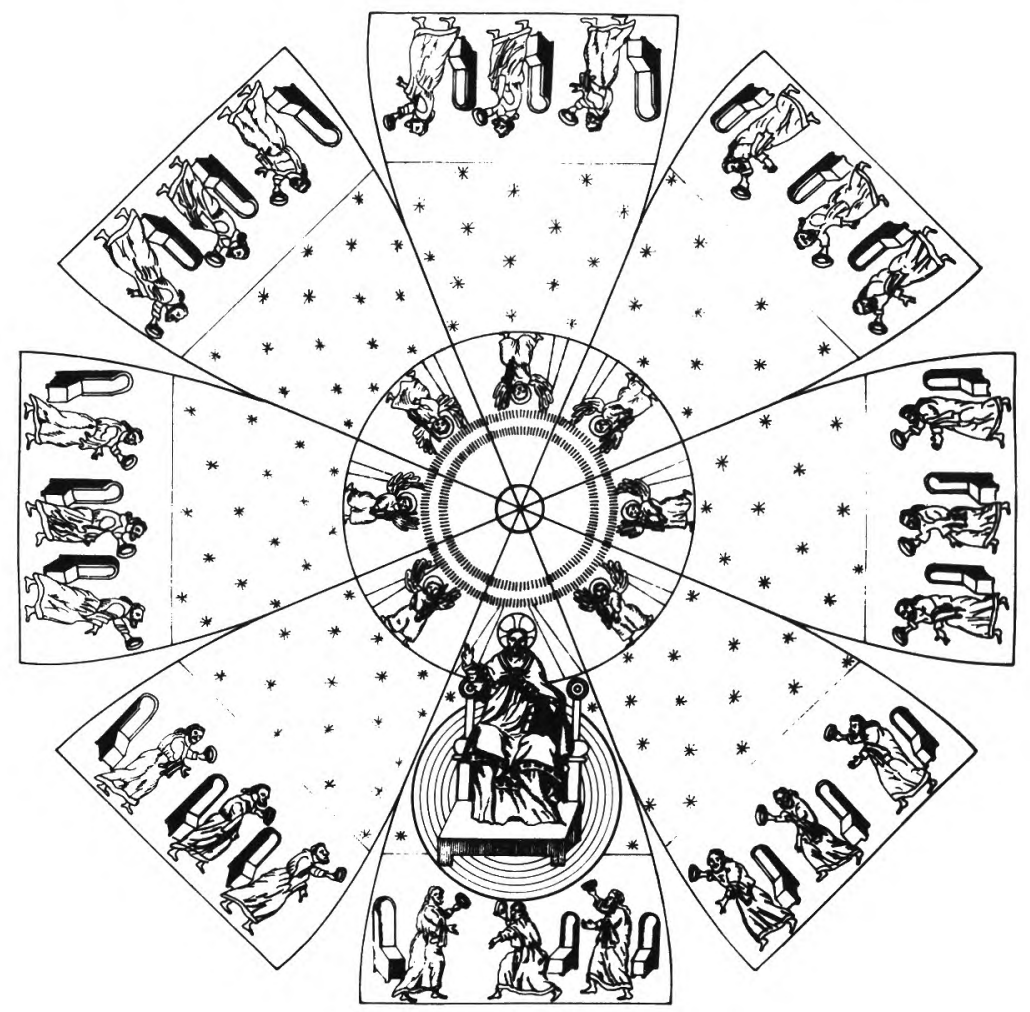




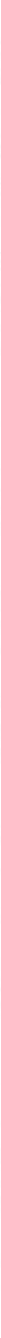

8. Rzym. Mozaika tęczy w bazylice śś. Kosmy i Damiana, VI w., wg Ciampiniego (fot. A. Rzepecki). 


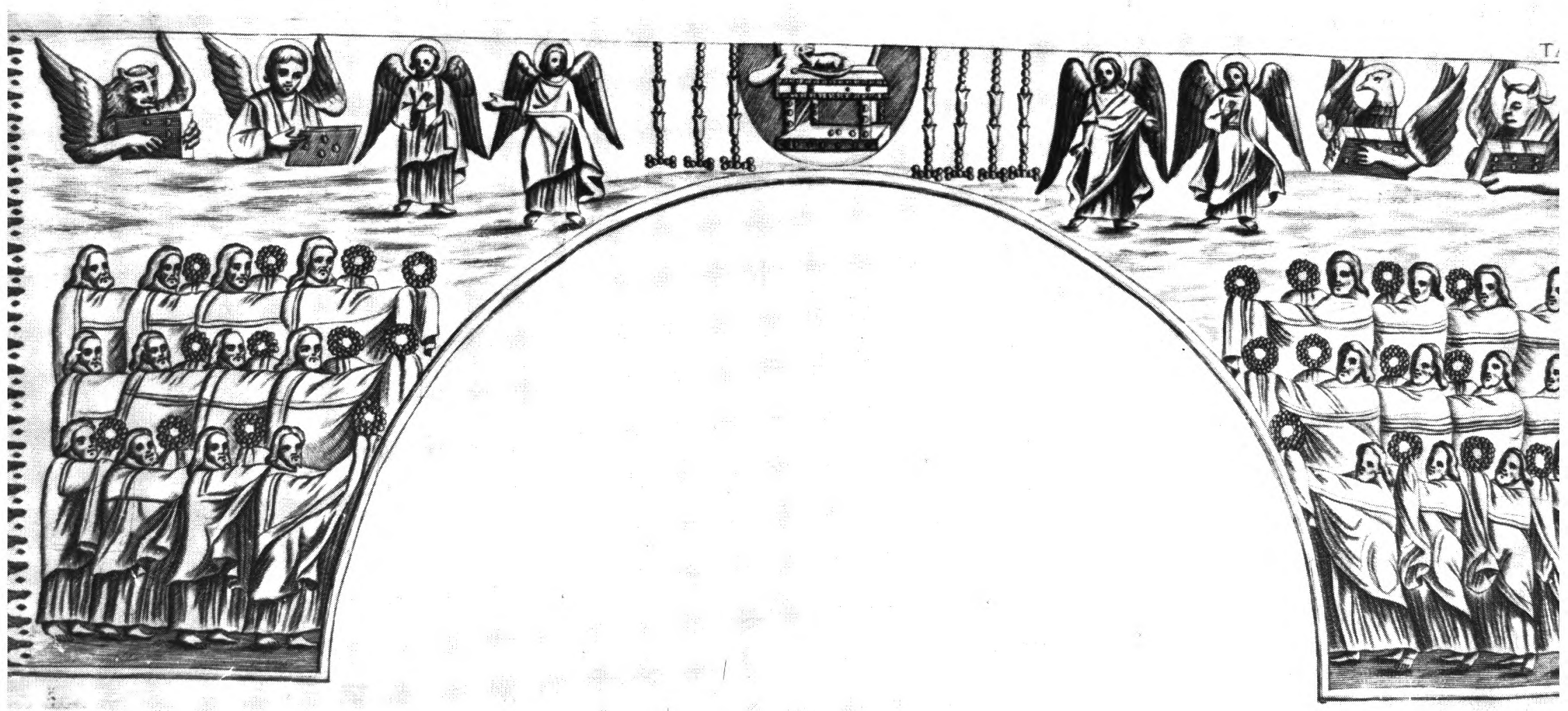

9. Rzym. Mozaika tęczy w bazylice św. Praksedy, ok. 817 r., wg Ciampiniego (fot. A. Rzepecki). 


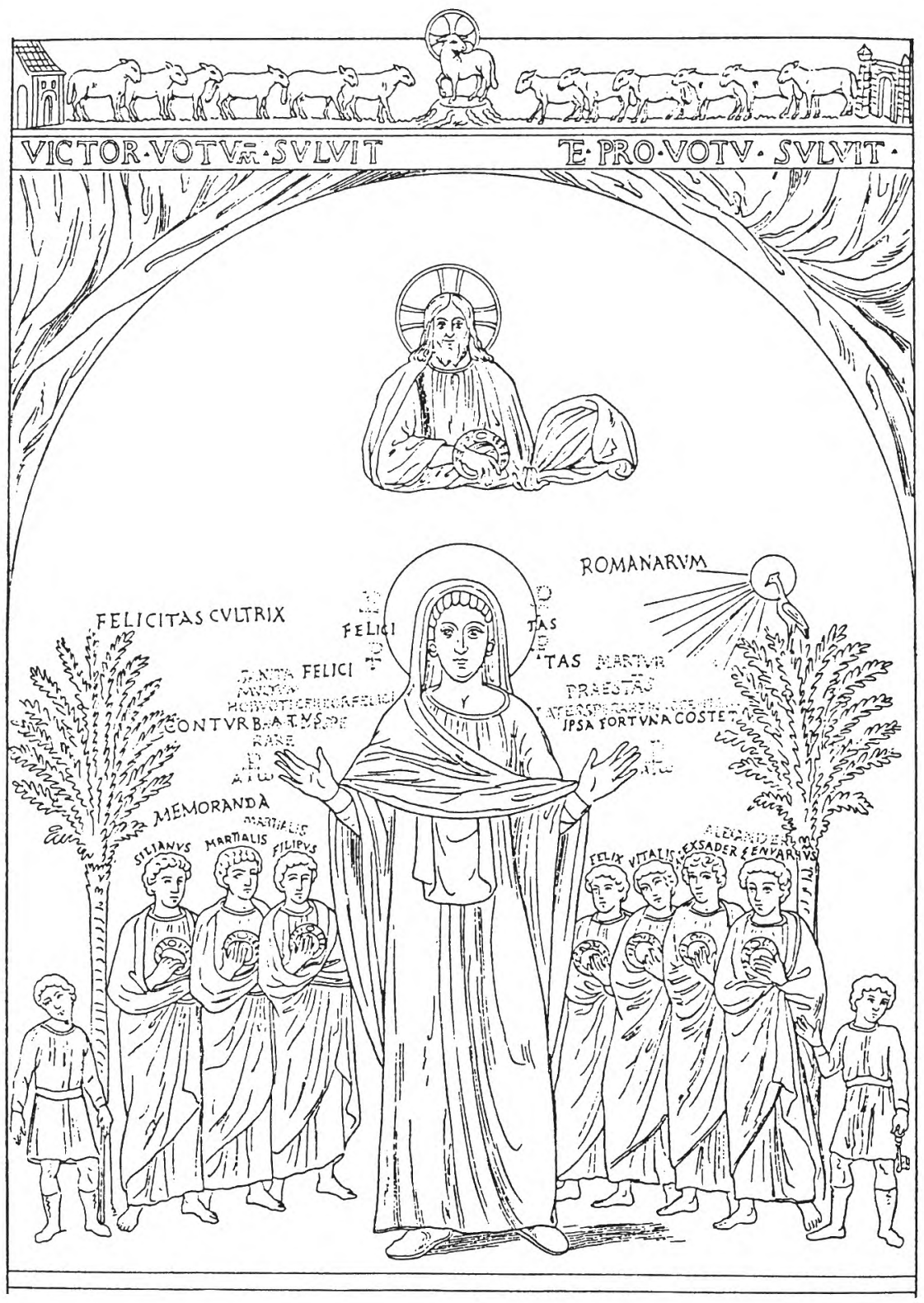

10. Rzym. Malowidło ścienne w oratorium św. Felicyty, wg Leclercq’a. 


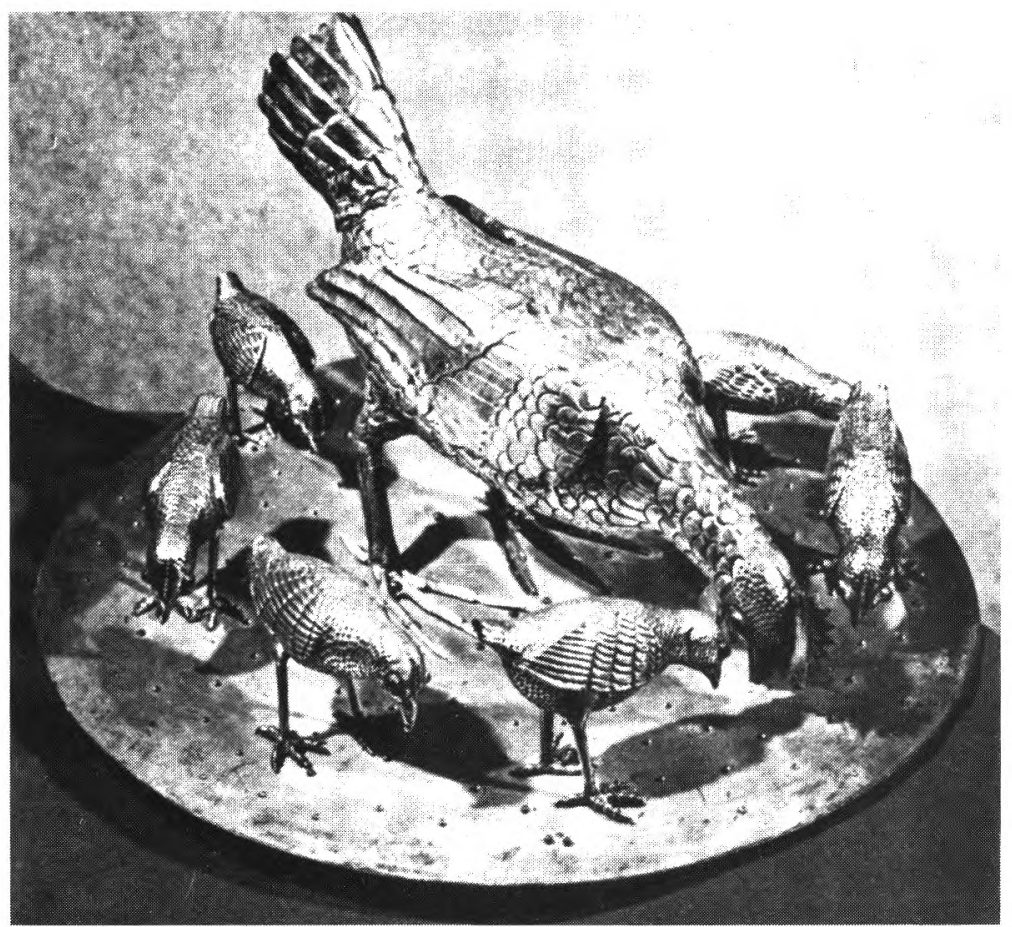

11. Monza. Skarbiec katedralny. Kura i siedem kurcząt, wg Verzonego.

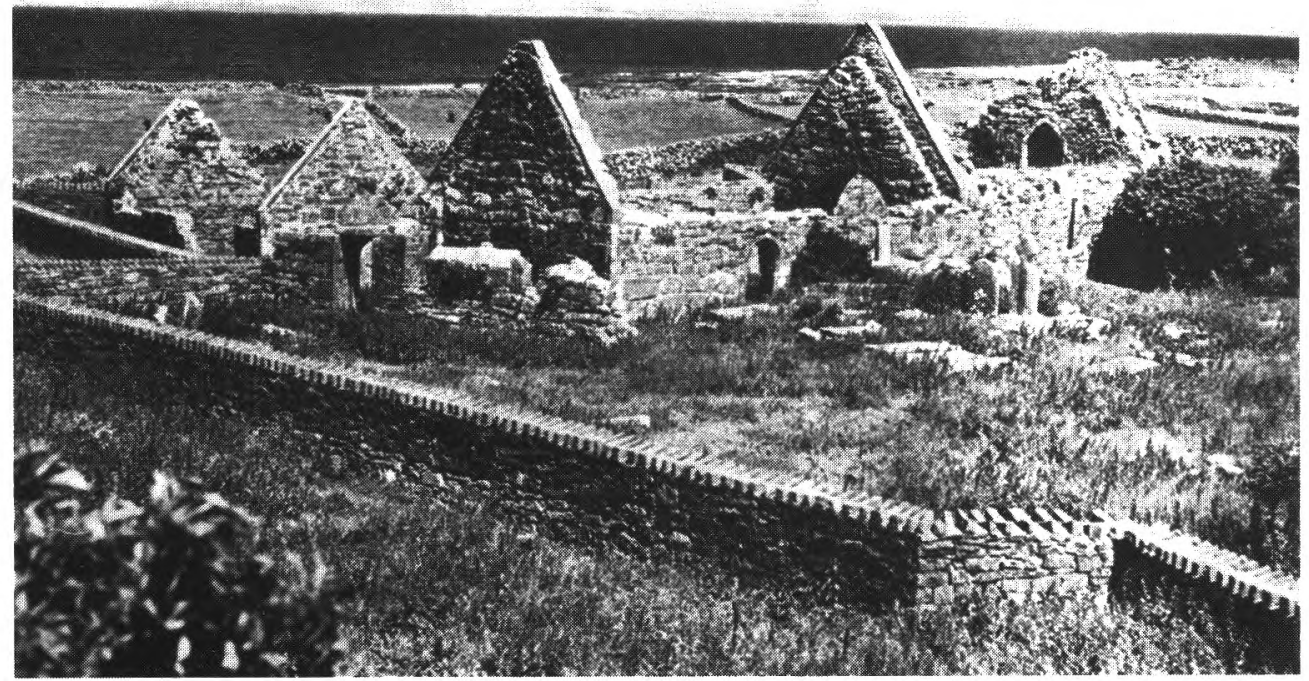

12. Inishmore. Seven Churches, wg Bielera (fot. A. Rzepecki). 
pisy na rycinach obrazujących owe siedem najstarszych kościołów wiecznego miasta (zob. il. 1,2).

\section{Sztuka}

Apokaliptyczna siódemka znalazła równiej swoje ważne miejsce w sakralnej sztuce, przede wszystkim monumentalnej ${ }^{43}$. Ideę jedności i uniwersalności Kościoła zawartą w obrazie siedmiu kandelabrów lub siedmiu aniołów z kandelabrami wprowadzano do najważniejszych miejsc kościołów, do ich sakrariów. W oparciu o tekst Apokalipsy i jego egzegezę Kościół rzymski zaakceptował w dekoracji budowli sakralnych pewnej hierarchii program ikonograficzny, powtarzany z małymi zmianami przez wiele wieków, a dający się wyśledzić już w IV w. Na ów program ,apokaliptyczny” (wyobrażany na ogół na tęczy bazylik, rzadziej w apsydach i w kopułach budowli centralnych) składało się kilka motywów: z obu stron tronującego Chrystusa albo też stojącego czy leżącego na ołtarzu Baranka ukazywano siedem kandelabrów lub siedem aniołów z kandelabrami w rękach, cztery zwierzęta apokaliptyczne i 24 starców. Obok Baranka kładziono zwój siedmiokroć zapieczętowany (zgodnie z Ap. 5, 1).

Egzegeci Apokalipsy nie pozostawili wątpliwości co do symbolizmu znaczeń ideowych tych przedstawień. W końcu wieku III pisał Wiktorinus, że ów Chrystus (,qui venturus est, utique ad judicandum”) pośród siedmiu kandelabrów jest jak Chrystus pośrodku kościołów i że księga z siedmioma pieczęciami to Stary Testament (CSEL 49, 20, 60). W IV w. Ticonius widział w tym motywie „tajemnicę jednego, siedmiokształtnego Kościoła”. Także Cezary z Arles pisal, że obrazują one cały Kościół, Chrystusa pośrodku Kościoła, a siedem kandelabrów to Kościół katolicki, a więc powszechny, pełen siedmiorakiej łaski Ducha św. ${ }^{44} \mathrm{~W}$ tym samym sensie wypowiedział się w VIII wieku Alkuin ${ }^{45}$. Jak wielką wagę przywiązywano do tego symbolicznego obrazowania, zawierającego tak syntetyczne treści, świadczyć może wybór miejsca dla jego przedstawiania, sferę „niebiańską", a więc tęczę, apsydę, kopułę.

Najstarsze, znane ze źródeł, wyobrażenie kandelabrów obok tronującego Chrystusa znajdowało się w środkowej apsydzie mauzoleum Konstancji w Rzymie (IV w.?) ${ }^{46}$. W świetle pisemnych przekazów występował ten temat

${ }^{43}$ Osobne zagadnienie stanowią ilustracje tekstu Apokalipsy o charakterze narracyjnym, jak w baptysterium katedry w Nowarze, w portyku opackiego kościola w Saint-Savin-sur-Gartempe, a także ilustracje do Apokalipsy, np. do Apokalipsy z Trewiru, z Valenciennes, Beatusy itp.

${ }^{44}$ PL 35 kol. $2417-2421$.

45 PL 100 kol. 1097.

46 Zapis Ugonia (Biblioteka w Ferrarze, rks 430 fol. 1103); C. Ih m, Die Programme der Christlichen Apsismalerei vom vierten Jahrhundert bis zur Mitte des achten Jahrhunderts, Wiesbaden 1960, s. $150-151 \mathrm{n}$. 
w pierwszej połowie V wieku w bazylice św. Jana Ewangelisty w Rawennie ${ }^{47}$, a także w Neapolu na tęczy bazyliki biskupiej pod wezwaniem Salwatora ${ }^{48}$, gdzie mógł być powtórzeniem wcześniejszej dekoracji, zniszczonej pożogą wojenną w V wieku i pożarem w pierwszej połowie VI wieku. Ukazano tu siedzącego Salwatora, siedem aniołów z kandelabrami i 24 Starców Apokalipsy (rys. 20). Identyczny program odnajdujemy dwa i pół wieku później w Akwizgranie, w epoce renesansu karolińskiego, w kopule kaplicy pałacowej pod wezwaniem Salwatora (il. 6) ${ }^{49}$.

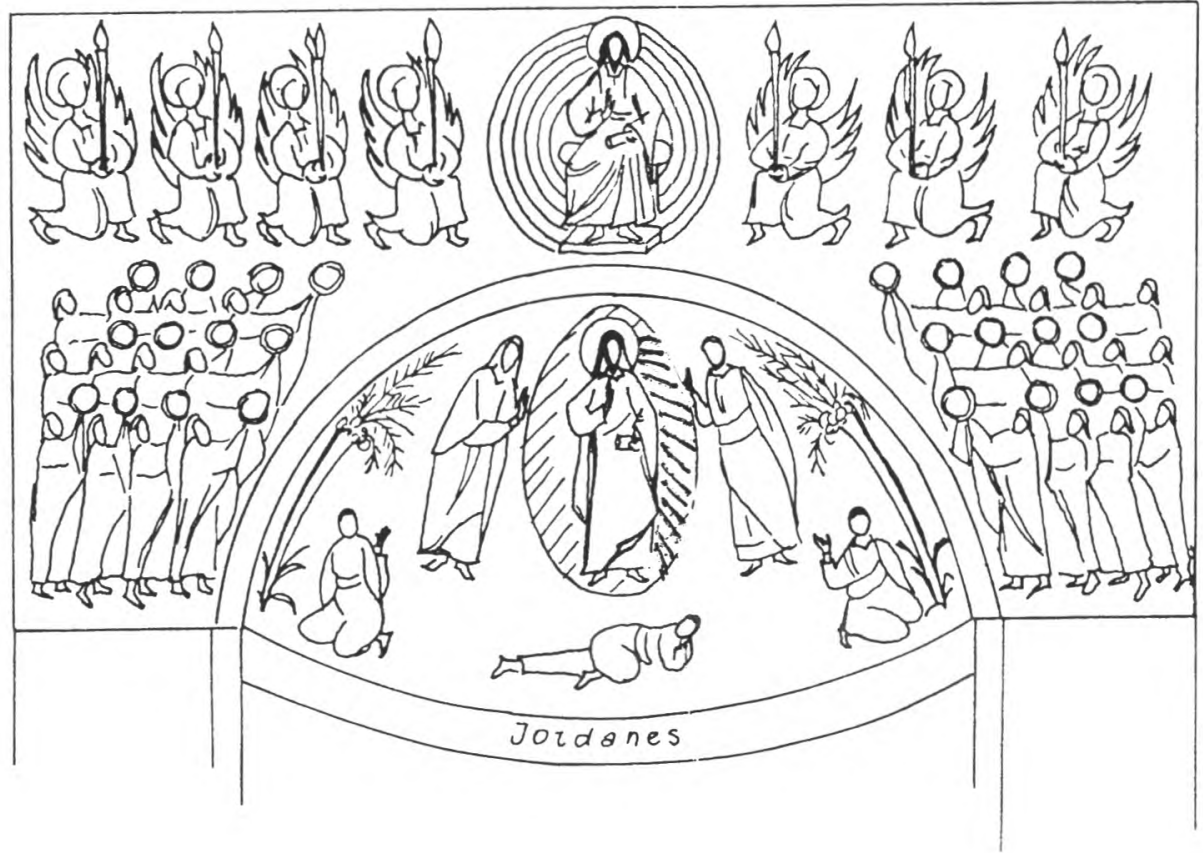

Rys. 20. Neapol. Rekonstrukcja mozaiki apsydy i tęczy w katedrze Salwatora (J. Kalinowska)

Najstarsza zachowana dekoracja tęczy z wyobrażeniem siedmiu kandelabrów pochodzi z wieku VI i znajduje się w rzymskiej bazylice śś. Kosmy i Damiana (il. 8). Zamiast Chrystusa występuje tam Baranek, zwój siedmiokroć za-

47 Angellus, Liber pontificalis, [w:] A. Testi Ras poni, Codex pontificalis Ecclesiae Ravennatis, t. 1, Bologna 1924, s. 74; H. Rossi, Historiarum Ravennatum libri decem, Wenecia 1572, s. 85-86; C. D a vis - We y e r, Early Medieval Art, Toronto 1986, s. 15-17.

${ }^{48}$ C. Ih m, jw., s. $176-177$.

49 J. Kali in ow s k a, Akwizgran, „Folia Historiae Artium” 18:1982 s. 14 (il. 9). 
pieczętowany, cztery Zwierzęta i Starcy (wyobrażenie tych ostatnich przetrwało tam w nikłych fragmentach). Na połowę VI wieku datuje się mozaikowy motyw siedmiu kandelabrów na zachodniej fasadzie bazyliki biskupiej w Parenzo (Poreč) w Jugosławii. Apokaliptyczna wizja teofaniczna w szczycie fasady jest już dziś nieczytelna, natomiast w XIX wieku P. Deperis widział tam jeszcze resztki wizerunku Salwatora siedzącego na tronie oraz „serię” skrzydeł anielskich ${ }^{50}$. Należy stąd wnosić, że ukazano tu Chrystusa zapewne wśród siedmiu aniołów ponad siedmioma kandelabrami (rys. 21).

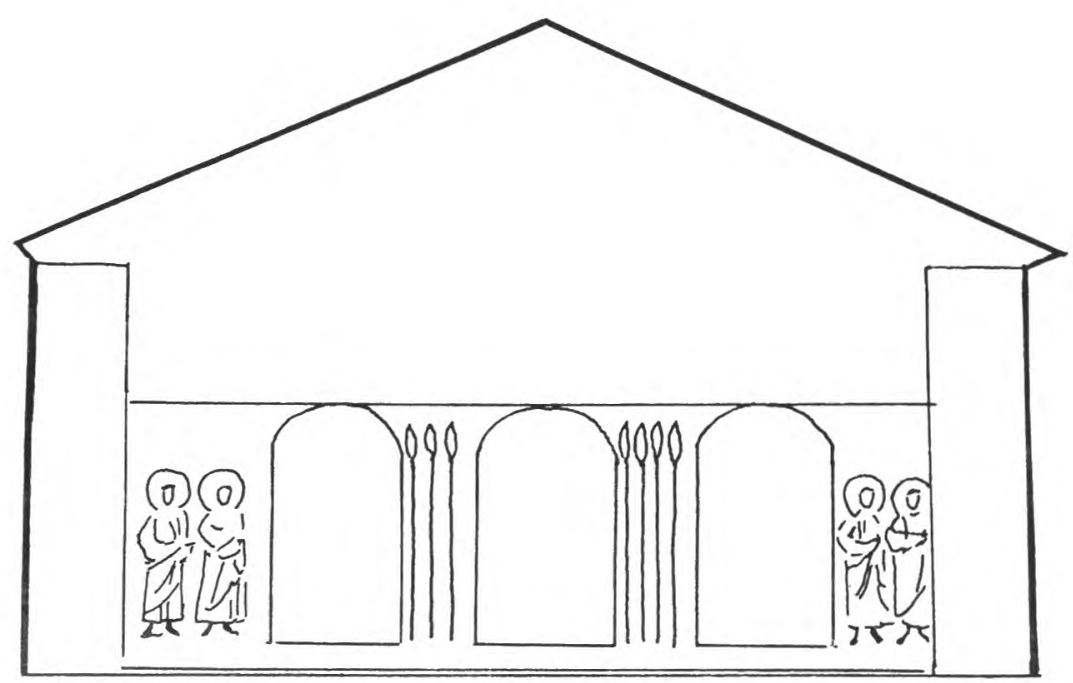

Rys. 21. Parenzo (Poreč). Mozaika na zachodniej fasadzie katedry p.w. Salwatora

Program dekoracji z apokaliptycznymi motywami: siedmiu kandelabrów, zwoju z siedmioma pieczęciami, czterema zwierzętami, dwudziestoma czterema starcami obok Chrystusa na tronie lub Baranka, powraca w dobie renesansu karolińskiego i paschalińskiego (VIII - IX w.). Zrealizowano go, jak już wspomniałam, w kopule kaplicy pałacowej pod wezwaniem Salwatora w Akwizgranie, a tuż przed połową roku 817 Paschalis I wprowadził go do nowej bazyliki św. Praksedy w Rzymie, powtarzając w niej zapewne, zgodnie z duchem ówczesnego renesansu, tematy dekoracji wczesnochrześcijańskiej bazyliki (il. 9). Siedem apokaliptycznych kandelabrów wyobrażono również w kościele Sta Maria in Trochio (jednego z siedmiu powiązanych symbolicznie z bazyliką Salwatora na Monte Cassino?). Widzi się je również wśród malowideł ściennych w starożytnej świątynce zwanej Fortuna virilis, poświęconej Matce Bożej

${ }^{50}$ P. D e pe r is, Il duomo di Parenzo e i suoi mosaici, „Atti Mem Soc Istriana” 11:1894 s. 192. 
(IX w. $)^{51}$. I dziś jeszcze apokaliptyczny Chrystus wśród siedmiu aniołów z płonącymi świecami w rękach dominuje na ikonostasie w grocie klasztoru św. Jana Ewangelisty na wyspie Patmos, miejscu Objawienia.

W sztuce wykorzystywano nie tylko motywy siedmiu aniołów i siedmiu kandelabrów, lecz wprowadzano także inne siódemki (nie zawsze proweniencji apokaliptycznej). W połowie wieku IV, kiedy jeszcze nie istniał zwyczaj dzielenia siódemek na 3 i 4, w jednej z trzech apsyd mauzoleum Konstancji w Rzymie „wtłoczono” wręcz siedem drzew oliwnych z jednej strony Chrystusa. Na tęczy bazyliki raweńskiej S. Michaele in Africisco rozmieszczono po jednej stronie tronującego Salwatora Powtórnego Przyjścia trzech, po drugiejczterech aniołów z trąbami w rękach (Ap. 8,2). W Rzymie zachowały się w katakumbach Maksyma i w oratorium św. Felicyty przedstawienia tej świętej stojącej poniżej półpostaci Chrystusa pośród siedmiu jej synów-męczenników, zgrupowanych jak kandelabry, z jednej strony trzech, z drugiej czterech. Ow zestaw postaci miał zapewne symbolizować „siedmiokształtny” Kościól (il. 10). Słynna kura z siedmioma kurczętami (VI w.) z Monzy byłaby nosicielką tego samego symbolizmu (il. 11) ${ }^{52}$. Na jednej z miniatur w Godzinkach księcia du Berry (Muzeum w Chantilly), siedmiu aniołów otacza górę św. Michała (Mont-Saint-Michel) z jej kościołami.

$\mathrm{Z}$ biegiem wieków słabło w Kościele zainteresowanie symbolizmami jedności Kościoła, idei tak żywej we współczesnej nam epoce. W wieku XVI, jak wyżej wspomniałam, odżyło z siłą dzięki wielkim animatorom myśli i zwyczajów wczesnochrześcijańskich, św. Filipowi z Neri i Cezaremu Baroniuszowi ${ }^{53}$. Na rok święty 1575 wykonano ryciny z wyobrażeniem siedmiu najstarszych rzymskich bazylik. Na jednej z nich ukazano sznury pielgrzymów odwiedzających „le sette chiese di Roma”, na innej (szczególnie ważnej dla naszych rozważań) umieszczono szereg tekstów z Apokalipsy i z Ewangelii, objaśniających znaczenie tematów występujących na rycinie. Ukazano na niej w centrum bazylikę Salwatora na Lateranie (tu pod imieniem św. Jana) i wokół niej pozostałe sześć kościołów: św. Piotra, Matki Bożej Większej, św. Wawrzyńca, św. Krzyża, św. Sebastiana i św. Pawła. Powyżej siedmiu kościołów stoi na obłokach siedmiu aniołów z kadzielnicami w rękach i obok nich siedem kandelabrów, a ponad nimi unosi się w obłokach Salwator w otoczeniu siedmiu świętych tytularnych siedmiu rzymskich kościołów. Z tekstów umieszczonych u dołu ryciny dowiadujemy się, że siedmiu świętych modli się o uniwersalność Kościoła, że siedmiu aniołów siedmiu kościołów, czyli Duch św., reprezentuje

$51 \mathrm{~J}$. La f on t a in e-Dosog ne, Peintures médiévales dans le temple dit de la Fortune virile à Rome, Bruxelles-Rome 1959, il. XX, XXI.

52 Biskup Akwilei Fortunatianus pisał w IV wieku, że siedem kurcząt symbolizuje siedem apokaliptycznych kościołów (N. Me zoug hi, Gallina significat sanctam Ecclesiam, „Cahiers Archéologiques" 35:1987 s. 53-59).

${ }_{53}$ L. von Pastor, The History of the Popes, t. 10, London 1923, s. 190-191; A. Hertz, jw., s. 593. 
Kościół powszechny, oświecony siedmioma darami Ducha św., a ogień świec w kandelabrach oznacza prawdziwą wiarę w Chrystusa (il. 1) $)^{54}$.

\section{MYSTERIUM SEPTIFORMIS ECCLESIAE}

\section{Résumé}

L'usage, autrefois enraciné profondément dans l'Eglise, de lier 7 sanctuaires avec une église de rang supérieur (qui parfois devenait la première de 7) et 7 autels avec un maître-autel, a échappé a l'attention des historiens de l'Eglise. Le groupement par 7 des églises, des chapelles, des autels, des lampes, des candélabres avait son origine dans l'Apocalypse de st. Jean et son exégèse. Selon l'Apocalypse „les sept candélabres sont les sept Eglises” (1:20), et selon la plus ancienne l'éxegèse du III ${ }^{\mathrm{e}} \mathbf{s}$. de Victorin de Pettau, l'ensemble des 7 églises auxquelles st. Jean dirigait ses lettres, c'est le symbol de l'unité de l'Eglise catholique illuminée par 7 esprits. Les mêmes idées expriment les écrivains postérieurs (Jérôme, Ticonius, Césaire d'Arles, Primase, Autpertus, Bède, Alcuin, Beatus, Berengaudus, Anselme de Laôn). Ils voyaient dans le 7 apocalyptique le nombre parfait, comportant l'idée de l'unité et de l'universalité de l'Eglise remplie de la grace des 7 dons du Saint Esprit, le „mystere de l'Eglise septiforme”.

L'Apocalypse influençait l'organisation septiforme de l'Eglise. Au III ${ }^{\mathrm{e}} \mathrm{s}$. Rome fut divisée en 7 régions ecclesiastiques avec 7 régions suburbaines et c'est à Rome que set ouve le plus ancien ensemble de 7 églises. Constantin le Grand a fondé la basilique épiscopale du Sauveur au Latran et 7 autres sanctuaires: le baptistère au Latran, Saint-Paul, Saints-Pierre-et-Marcellin, Saint-Croix, Saint-Laurent et Sainte-Agnès. Avec le temps on en élimina deux églises: Saints-Pierre-et-Marcellin et Sainte-Agnès, en introduisant Sainte-Marie-Majeure et Saint-Sébastien. Ces 7 églises (primitivement 1 plus 7) sont vénérées et connues comme „le sette chiese di Roma”. Quand le nombre des églises augmentait, on les groupait par 7, en les subordonnant à Rome à une de 4 restantes basiliques patriarcales. On peut trouver aussi à Constantinople les traces du système septiforme. Vers 324 l'empereur Constantin a établi (?) 7 regions suburbaines dont noms furent derivés des dombres de 1 a 7 . Dans la septième, dit Hebdomon, Constantin éléva l'église dédiée à st. Jean Evangéliste, l'auteur de l'Apocalypse. Carthage était aussi divisée en 7 régions ecclesiastiques; à Milan, à Bologne, à Soissons, à Inishmore (Irlande) on a bâti 7 sanctuaires; en Andenne sur Meuse ste Beghue a fait élévés 7 églises. (La place pour elles aurait été indiquée par une poule et ses 7 poussins; la célèbre poule de Monza, symbole de l'Eglise septiforme, indiquerait - elle une fondation analogue?). Sur une miniature du $\mathrm{XI}^{\mathrm{e}} \mathrm{s}$. le Mont - Cassin avec ses 2 basiliques est entouré par 7 églises. En Pologne, à Cracovie, la cathédrale préromane était entourée probablement par 7 chapelles. Au XII $\mathrm{s}$. le chevalier polonais Pierre Włost fonda 7 églises (ou 70, ou plutôt 7 églises et 7 fois 7 chapelles?). Après le baptême de la Lithuanie, le roi Władysław Jagiełlo a élévé la cathédrale à Wilno et 7 églises en Province. A Moravie, le „type septenaire” fut peut - être réalisé à Miculčice. En Ethiope, à Roha, le roi Lalibela a fait creuser (vers 1200) dans le rocher 2 grandes églises (la cathédrale doubre, la famille cathédrale) et 7 sanctuaires. On pourrait ettribuer à la même tradition les choeurs des églises romanes et gothiques aux 7 chapelles rayonnantes. A l'Orient chrétien l'organisation

${ }^{54}$ Inskrypcje na rycinie z wyobrażeniem siedmiu rzymskich kościołów, Salwatora, siedmiu aniołów, siedmiu kandelabrów i siedmiu tytularnych świętych kościołów (zob. wyżej przypis 8). 
septiforme de l'Eglise était aussi strictement respectée (Pskov, Moscou, Kiev, Novgorod; on pourrait la déchiffrer en Grèce: Athos, Mistra, Meteora).

Le 7 dominait dans l'aménagement des interieurs des élises (avant tout épiscopales et abbatiales). Constantin le Grand a offert à la basilique du Sauveur au Latran 7 autels, 7 candélabres, 7 patènes (et sept figures des cerfs au baptistère); a l'église du Sauveur à Aniane Charlemagne a donné: 7 autels, 7 candélabres, 7 lampes et 7 candélabres a la basilique de Saint-Denis (au XII ${ }^{\mathrm{s}}$ s. Suger les remplaca par les 7 nouveaux). Angilbert a introduit (vers 799) 7 autels de stations à l'église du Sauveur à Centula. En 878 le pape Jean VIII consacra 7 autels dans l'église abbatiale du Sauveur à Flavini. A Germigny-des-Prés, l'oratoire du Sauveur possédait sans doute 7 autels. Encore au XVIII ${ }^{\mathrm{e}}$ s. (Wawel) et même au XX ${ }^{\mathrm{e}}$ s. (Brugge, Zevenkerken, „Sept Eglises”) on a arrangé 7 autels privillegiés qui portaient souvent les mêmes vocables que „le sette chiese di Roma”.

Les lectures apocalyptiques constituient en élément important de la liturgie pascale latine depuis l'époque paléochrétienne. Les 7 chandeliers portés par 7 acolythes accompagnaient le pape quand il entrait dans la basilique du Sauveur au Latran pour célébrer la Messe. On portait 7 chandeliers à côté du prêtre postant le livre de l'Evangile. Au Moyen Age, et même au XVII's. on célébrait „fêtes à 7 chandeliers” en l'honneur de st. Jean Evangéliste. Le 7 regnait dans l'ordre processionnell on désignait par 7 les cardinaux, les évêques, les diacres, les acolithes etc.

On retrouve ce nombre dans l'art. Les visions synthétiques de l'Apocalypse du Jean occupaient les plus importantes de l'église: l'abside, l'arc triomphal, la coupole. On y représentait le Sauveur trônant entouré par 7 anges et 7 candélabres (les églises épiscopales du Sauveur à Naples et à Aix-la-Chapelle), ou l'Agneau mystique avec 7 chandeliers, 4 Vivants, avec le livre „roulé scellé de 7 sceaux" et 24 Vieillards (Ss Come et Damien, Sainte-Praxède - les martyria).

Avec le temps la vivacité des symbolismes de 7 s'effaçait. Au XVI ${ }^{\mathrm{e}} \mathrm{s}$. leurs grands animateurs étaient: st. Philippe Néri et cardinal César Baronio. L'ancienne coutume du pèlerinage aux „le sette chiese di Roma" a été renouvelé. Pour célébrer l'an saint 1575 on a fait éxécuter plusieurs gravures avec les images des ,sept églises romaines”. Sur une d'elles tout le programme paléochrétien est lisible. On y voit le Sauveur, 7 saints titulaires, 7 anges, 7 candélabres et 7 églises. La legende explique que 7 saints prient pour l'universalité de l'église, que 7 anges de 7 églises, c'est-à-dire l'Esprit Saint, representent l'Eglise universelle. Le program iconographique de cette gravure prouve la durabilité des idées ex primées par 7 églises, 7 anges et 7 candélabres apocalyptiques, les idées renouvelées dans notre époque par les successeurs de st. Pierre à Rome. 